\title{
TAKLIF DEWASA DINI DALAM HUKUM ISLAM (Analisis Pubertas Prekoks dan Gifted)
}

\author{
Aprianif \\ (aprianif@gmail.com) \\ Dosen Sekolah Tinggi Ilmu Tarbiyah (STIT) Islamic Village Tangerang
}

\begin{abstract}
Abstrak: Permasalahan yang diangkat dalam penelitian ini adalah mempertanyakan hakikat taklif atau pertanggungjawaban hukum dalam hukum Islam. Kemudian dikaitkan dengan fenomena dewasa dini berupa pubertas prekoks dan gifted. Penelitian ini mendukung pendapat Ibn Qayyim al-Jauziyyah, Muhammad Abu Zahrah dan Subhi Mahmasani yang mengatakan bahwa perubahan dalam hukum Islam biasa terjadi. Hukum Islam bisa berubah-ubah dengan berbedanya keadaan, tempat dan waktu. Sekaligus penelitian ini menolak pendapat Abid Muhammad as-Sufyani dan Muhammad Muslehuddin yang mengatakan bahwa hukum Islam tidak dapat berubah-ubah. Sumber yang dipakai dalam penelitian ini adalah buku-buku yang berhubungan dengan konsep taklif, dewasa dini dan perubahan-perubahan hukum dalam hukum Islam dengan menjadikan data primernya berupa kitab I'lam al-Muwaqi'in 'an Rabbil 'Alamin karangan Ibn Qayyim al-Jauziyah. Penelitian ini merupakan penelitian kepustakaan yaitu penelitian yang mengunakan bahan-bahan kepustakaan yang ada kaitannya dengan masalah pokok penelitian ini sebagai sumbernya. Pendekatan yang digunakan adalah pendekatan sosiologi hukum milik Ibn Qayyim al-Jauziyyah yang mengatakan bahwa hukum bisa berubah-ubah dengan berubahnya keadaan, waktu dan tempat.
\end{abstract}

Kata kunci: Taklif, Pubertas Prekoks, Gifted.

\section{A. Pendahuluan}

Salah satu periode penting dalam perjalanan kehidupan manusia adalah masa pubertas. Suatu masa dimana pertumbuhan dan perubahan fisik manusia terjadi sangat pesat. Waktunya tidak lama, terjadi antara akhir masa kanak-kanak dan permulaan masa remaja. ${ }^{123}$ Dimasa ini biasanya seseorang akan mengalami mimpi basah atau menstruasi, yang itu menandakan bahwa organ reproduksinya telah matang atau biasa disebut dengan telah mencapai kematangan seksual. ${ }^{124}$ Kematangan seksual itu adalah kematangan kelenjar kelamin yaitu testis pada

${ }^{123}$ Jhon W Santrock, Remaja, Edisi Kesebelas (Jakarta: Erlangga, 2007), 83. Diterjemahkan oleh Benedictine Widyasinta dengan judul asli Adolescence, Eleventh Edition.

${ }^{124}$ Dirjen Pembinaan Kesehatan Masyarakat Departemen Kesehatan RI, "Materi Inti Kesehatan Reproduksi Remaja" (Jakarta: Depkes RI, 2001). 
ISTIGHNA, Vol. 1, No 1, Januari 2018 P-ISSN 1979-2824

Homepage: http://e-journal.stit-islamic-village.ac.id/index.php/istighna

Aprianif

Taklif Dewasa Dini Dalam Hukum Islam

(Analisis Pubertas Prekoks dan Gifted)

anak laki-laki dan ovarium pada anak perempuan beserta membesarnya alat-alat kelaminnya. $^{125}$

Pubertas merupakan suatu proses yang alami dan hampir pasti dialami oleh setiap manusia. Ketika masa itu datang, maka akan terjadi perubahan fisik pada diri manusia tersebut, dari yang mulanya bertubuh layaknya anak-anak menjadi bertubuh layaknya orang dewasa. Seiring dengan itu, ia juga akan memiliki kemampuan untuk bereproduksi. Ini terjadi disebabkan karena adanya suatu sistem hormon yang berasal dari otak, kemudian ia menuju gonad, dan gonadpun meresponnya dengan menghasilkan berbagai hormon yang menstimulasi pertumbuhan dan perkembangan fungsi transformasi otak, tulang, otot, kulit, payudara dan organ-organ reproduksi lainnya. Proses ini (proses pubertas ini), sekaligus juga menandai peningkatan kematangan psikologis seorang manusia yang secara sosial disebut dengan telah menjadi seorang yang sudah dewasa. ${ }^{126}$

Pubertas umumnya dialami oleh seorang manusia sekitar usia sebelas sampai enam belas tahun. Dengan rincian anak perempuan antara usia sebelas sampai lima belas tahun dan anak laki-laki di usia dua belas sampai enam belas tahun. Tetapi ini hanyalah teorinya saja, karena pada kenyataannya pertumbuhan dan perubahan yang terjadi pada diri seorang manusia bisa berbeda-beda tergantung kepada individunya. Karena memang pubertas ini sebenarnya sangat dipengaruhi oleh banyak faktor, seperti keturunan, lingkungan, gizi, kesehatan dan tekanan emosional. ${ }^{127}$

Tetapi kemudian pada masa pubertas ini dapat pula terjadi kelainankelainan, seperti pubertas tarda (delayed puberty) dan pubertas prekoks (precocious puberty). Dikatakan pubertas tarda, apabila seseorang belum mencapai pubernya padahal usianya sudah mencapai 18 tahun. ${ }^{128}$ Sebaliknya,

\footnotetext{
${ }^{125}$ Kartini Kartono, Psikologi Wanita 1 Mengenal Gadis Remaja dan Wanita Dewasa (Bandung: Mandar Maju, 1992), 53.

${ }^{126}$ Mayo Clinic Staff, "Precocious Puberty", Mayo Foundation, Diunduh 12 Desember 2012 dari http://mayoclinic.com/article/precociouspuberty-definition. December $12^{\text {th }} 2012$.

${ }^{127}$ FJ Monks, AMP Knoers, Siti Rahayu Haditono, Psikologi Perkembangan: Pengantar Dalam Berbagai Bagiannya (Yogyakarta: Gadjah Mada University Press, 2002), 263.

${ }^{128}$ Menarche adalah menstruasi kali pertama, yaitu keluarnya cairan darah dari alat kelamin wanita karena luruhnya lapisan dinding dalam rahim yang banyak mengandung pembuluh darah. Menstruasi atau yang biasa disebut dengan haid ini, itu mengacu pada pengeluaran secara periodik
} 
ISTIGHNA, Vol. 1, No 1, Januari 2018 P-ISSN 1979-2824

Homepage: http://e-journal.stit-islamic-village.ac.id/index.php/istighna

Aprianif

Taklif Dewasa Dini Dalam Hukum Islam

(Analisis Pubertas Prekoks dan Gifted)

ketika seseorang mendapati pubernya atau menarche-nya bagi anak perempuan di usianya yang sangat muda, sebelum usia 8 atau 9 tahun, maka ini disebut dengan pubertas prekoks. ${ }^{129}$ Penyebab dari pubertas prekoks ini bisa bermacam-macam. Bisa karena dipicu oleh otak secara spontan dan bisa juga karena adanya pengaruh dari luar tubuh manusia. Biasanya prosesnya dimulai diakhir masa kanak-kanak yang ditandai dengan munculnya tanda-tanda kematangan organ reproduksi lebih awal dan dengan telah berakhirnya masa pertumbuhan. ${ }^{130}$

Munculnya fenomena ini (keberadaan pubertas prekoks) menimbulkan banyak pertanyaan. Baik dikalangan akademisi hukum ataupun masyarakat luas terutama bagi kaum Muslimin (orang-orang yang menganut agama Islam). Karena di dalam agama Islam hal ini sangat erat kaitannya dengan konsep pendidikan Islam dan pembebanan hukum atau taklif dalam hukum Islam. ${ }^{131}$

Karena pada teorinya, apabila seorang anak yang sudah menstruasi atau keluar air mani, maka ia dianggap sebagai seorang yang sudah taklif atau mukallaf (seseorang yang sudah dibebani hukum). Resikonya, ketika ia sudah dianggap sebagai seorang yang mukallaf, maka ia harus melaksanakan semua kewajibankewajiban agama yang ditujukan kepadanya, baik itu yang berupa syari'ah ataupun mu'amalah. Oleh sebab itu seandainya si anak melakukakan suatu kejahatan, maka ia harus mempertanggungjawabkan perbuatannya tersebut dihadapan hukum. Masalahnya, apabila dilihat dari sisi psikologis dan sosialogis, si anak ini belumlah pantas sedikitpun untuk bisa dikategorikan sebagai seorang

darah dan sel-sel tubuh dari vagina yang berasal dari dinding rahim wanita, yang biasanya itu dimulai saat pubertas dan sekaligus menjadi tanda bahwa perempuan tersebut sudah mampu untuk mengandung anak. Lihat Proverawati A dan Misaroh S, Menarche menstruasi pertama yang penuh makna (Yogyakarta: Muha Medika, 2009), 21.

${ }^{129}$ Pubertas tarda adalah sebuah peristiwa dimana seseorang wanita telah mencapai usia 18 tahun namun belum juga mendapatkan haid. Secara khusus untuk anak perempuan batasan pubertas tarda itu adalah apabila belum ada perkembangan payudaranya setelah 5 tahun menarche atau belum menarche pada usia 16 tahun (amenore primer). Lihat Usman Said, "Interaksi Hormonal dan Kualitas Kehidupan Pada Wanita", Diseminarkan pada simposium pengaruh hormonal pada kualitas kehidupan, Dies natalis FK UNSRI ke 42, Palembang 2 Oktober 2004.

${ }^{130}$ Behrman RE, Kliegman RM, Jenson HB, Nelson Textbook of Pediatrics, Edisi 17 (Philadelphia: Saunders Elsevier Science, 2004) 1926-1935. Kemudian dijelaskan oleh Haslam RHA dalam bab Endokrine System.

${ }^{131}$ Kata taklif itu berasal dari bahasa Arab, mustaq dari fi'il madhi kallafa. Dalam Islam ia digunakan sebagai sebuah istilah yang berkaitan dengan pembebanan dan pertanggungjawaban hukum yang terdapat dalam hukum Islam. Lihat Abdullah Ibn Ahmad Ibn Qudamah, Raudhah anNadhir (Riyad: Jami'ah al-Imam Muhammad Ibn Su’ud, 1399 H), 46-47. 
ISTIGHNA, Vol. 1, No 1, Januari 2018 P-ISSN 1979-2824

Homepage: http://e-journal.stit-islamic-village.ac.id/index.php/istighna

Aprianif

Taklif Dewasa Dini Dalam Hukum Islam

(Analisis Pubertas Prekoks dan Gifted)

manusia dewasa. Bahkan dikehidupan nyata mereka ini masih tetap dianggap anak-anak oleh masyarakat disekitarnya.

Setelah fenomena pubertas prekoks ini, muncul pertanyaan lain, bagaimana pula dengan anak-anak gifted (anak-anak berbakat). Anak-anak yang pemikirannya lebih cepat dewasa dibanding fisiknya. Bila pubertas prekoks fisiknya lebih cepat dewasa dari pemikirannya, yang ini sebaliknya, pemikirannya sudah dewasa, tetapi fisiknya belum. Anak-anak ini merupakan anak-anak jenius dan memiliki IQ yang tinggi. Pertanyaaannya, bagaimanakah taklif kedua anakanak ini. Apakah hukum Islam memandang manusia hanya sebagai makhluk biologis ataukah sebagai makhluk sosiologis. Adakah masalah taklif ini hanyalah masalah biologis ataukah masalah filosofis. ${ }^{132}$ Untuk menjawab semua pertanyaan yang menganjal inilah penulis berusaha mengkaji ulang dan mengangkat permasalahan ini kembali.

\section{B. Pubertas, Pubertas Prekoks dan Gifted}

1. Mengenal Pubertas dan Pubertas prekoks

Berbicara mengenai pubertas, pubertas adalah suatu istilah yang berasal dari bahasa latin (pubescere) yang artinya adalah mendapatkan pubes atau rambut kemaluan, yaitu suatu tanda kelamin sekunder yang menunjukkan perkembangan seksual seseorang. Istilah ini dipakai atau dimaksudkan untuk remaja sekitar masa pemasakan seksual. ${ }^{133}$ Dulu Nabi Muhammad Saw menggunakan konsep ini untuk membedakan mana seseorang yang sudah dewasa dan mana yang masih anak-anak. ${ }^{134}$

\footnotetext{
${ }^{132}$ Kata Gifted itu berasal dari bahasa Inggris. Ia ditujukan kepada seseorang yang mempunyai inteligensia yang tinggi di atas rata-rata (di atas skor 130), mempunyai kreatifitas yang tinggi serta motivasi dan komitmen kerja yang juga tinggi. Pengertian ini dikemukakan oleh Renzulli, seorang ahli anak gifted dari Amerika. Hal yang sama juga disampaikan oleh JF Monk, seorang guru besar psikologi anak berbakat di Belanda. Beliau adalah direktur European Council for High Ability. Lihat Julia Maria Van Tiel, Anakku Terlambat Bicara (Jakarta: Prenada Media Group, 2008), 5.

${ }^{133}$ Aliyah B Purwakania Hasan, Psikologi Perkembangan Islami (Jakarta: PT RajaGrafindo Persada, 2008), 109.

${ }^{134}$ Lihat Hadist Rasulullah Saw ketika perang Bani Quraizah yang artinya "diriwayatkan oleh At-Tiyah Al-Qurazi, dia berkata "Kami telah dihadapkan kepada Nabi Saw pada perang Bani Quraizah. Barangsiapa yang telah tumbuh (rambut kemaluannya), maka dia dibunuh, dan barangsiapa yang belum tumbuh (rambut kemaluannya), maka dia akan tetap hidup. Dan aku merupakan salah seorang dari mereka yang dibiarkan hidup." Hadist riwayat at-Tirmidhi dan an-
} 
ISTIGHNA, Vol. 1, No 1, Januari 2018 P-ISSN 1979-2824

Homepage: http://e-journal.stit-islamic-village.ac.id/index.php/istighna

Aprianif

Taklif Dewasa Dini Dalam Hukum Islam (Analisis Pubertas Prekoks dan Gifted)

Pubertas merupakan suatu tahap penting dalam proses tumbuh kembang seseorang. Perkembangan ciri-ciri seksual sekunder, perubahan komposisi tubuh, perubahan maturasi tulang, menutupnya epifisis dan terbentuknya perawakan akhir dewasa terjadi pada masa ini, dan ini semua disebabkan karena adanya perubahan hormonal yang hanya berlangsung pada masa pubertas. Karena itu pubertas sebenarnya merupakan suatu proses biologis kompleks yang kelansungannya terjadi dalam beberapa tahap dan dipengaruhi oleh beberapa faktor seperti genetik, nutrisi, lingkungan, sosial dan ekonomi. Faktor-faktor inilah yang bertanggung jawab atas awitan dan perkembangan seorang manusia guna menuju maturitas seksual yang lengkap. ${ }^{135}$

Pubertas merupakan suatu tahapan dalam proses pertumbuhan dan perkembangan kontinu. Pada saat pubertas ini terjadi akan terjadi pacu tumbuh, tercapai fertilitas, munculnya perubahan kognitif dan psikologis, ada perubahan morfologis dan fisiologis serta tidak ketinggalan juga akan terjadi maturasi dari sistem reproduksi yang timbul karena adanya perubahan aktivitas endokrin secara sekuensial dan teratur. ${ }^{136}$

Tetapi selanjutnya, dalam prosesnya pubertas ini tidak senantiasa berjalan normal. Sering terjadi kelainan-kelainan. Secara umum sebagaimana yang sudah disebutkan dimuka ada dua macam kelainan yang terjadi pada pubertas yaitu pubertas terlalu dini atau yang biasa disebut dengan pubertas prekoks yang merupakan inti dari penelitian ini dan pubertas tarda atau pubertas terlambat. ${ }^{137}$

Pubertas dikatakan sebagai pubertas prekoks atau precocious puberty apabila tanda pubertas seseorang muncul lebih awal dari biasanya. Bila biasanya pubertas itu dimulai antara usia 10 sampai 14 tahun pada anak

Nasai. Lihat Abu 'Isha at-Tirmidhi, Sunan at-Tirmidhi (Beirut: Dar al-Kutub al-'Ilmiyyah, t.thn), Hadist ke 1584, 1125.

${ }^{135}$ Aliyah B Purwakania Hasan, Psikologi Perkembangan Islami, 111.

${ }^{136}$ Elizabeth B Hurlock, Psikologi Perkembangan: Suatu pendekatan Sepanjang Rentang Kehidupan, Edisi 5, (Jakarta: Erlangga, 1980), 206.

${ }^{137}$ Behrman RE, Kliegman RM, Arvin AM, Nelson, Ilmu Kesehatan Anak, Vol III, Edisi XV (Jakarta: EGC, 2002), 1925-1934. Diedit oleh A Samik Wahab. 
ISTIGHNA, Vol. 1, No 1, Januari 2018 P-ISSN 1979-2824

Homepage: http://e-journal.stit-islamic-village.ac.id/index.php/istighna

Aprianif

Taklif Dewasa Dini Dalam Hukum Islam

(Analisis Pubertas Prekoks dan Gifted)

perempuan dan usia 12 sampai 16 tahun pada anak laki-laki, maka pada pubertas prekoks, anak perempuan akan mengalami gejala pubertas atau mendapati tanda pubertasnya pada usia kurang dari 8 tahun dan anak lakilaki pada usia kurang dari 9 tahun. ${ }^{138}$ Hal ini sebenarnya bisa merupakan bagian dari variasi perkembangan yang normal, namun bisa juga merupakan penyakit atau pertumbuhan hormon yang tidak normal. ${ }^{139}$

Anak-anak yang menderita pubertas prekoks ini biasanya mengalami beberapa masalah. Salah satunya adalah masalah tinggi badan. Biasanya tinggi badan mereka akan abnormal (tidak normal). Awalnya memang mereka ini kelihatan memiliki tinggi badan lebih tinggi dibandingkan dengan anak-anak seusianya. Tetapi pada kelanjutannya karena maturasi tulangnya lebih awal dan cakram episifisnya menutup lebih cepat, maka pertumbuhan mereka berhenti lebih cepat juga. Inilah alasannya kenapa anak-anak pubertas prekoks memiliki tinggi badan lebih rendah dari yang seharusnya mereka miliki dan tubuh mereka biasanya akan lebih pendek dibandingkan dengan teman-teman seusianya ketika telah mencapai usia dewasa. ${ }^{140}$

Selain masalah tinggi badan, biasanya mereka juga memiliki masalah sosial dan emosional. Mereka biasanya akan menunjukkan perubahan suasana hati seperti lekas marah dan suka murung pada anak perempuan dan menjadi agresif serta dimulainya perjalanan seks yang tidak tepat pada anak laki-laki. Perubahan-perubahan yang terjadi pada diri mereka ini membuat mereka menjadi agak berbeda jika dibandingkan dengan anak-anak sebayanya. Tidak jarang banyak diantara mereka yang merasa malu dengan perubahan-perubahan tersebut, terutama anak perempuan (karena

${ }^{138}$ Delemarre Van de Waal, Central Regulation of Human Puberti, Disertasi di Vrije Universiteit te Amsterdam, 1984. Lihat juga Jose RL Batubara, Adolescent Development (Perkembangan Remaja), Departemen Ilmu Kesehatan Anak RSCM dan Universitas Indonesia, Seri Pediatri, Vol XII, No I, Juni 2010. http://www.scribd.com/doc/244707171/jurnal-pubertasnormal-pdf\#scribd.

${ }^{139}$ JL Fahmi, JK Kaminsky, F Kaufman, MD Nelson, MT Parisi, The Radiological Approach to Precocious Puberty, The British Journal of Radiology, Vol 73, 560-567, 2000. Diakses dari http://bjr.birjournals.org/cgi/reprint/73/869/560.pdf.

${ }^{140}$ Styne DM, Puberty, Dalam Greenspan FS, Basic and Clinical Endrocrinology 3, Edisi III, (San Fransisco: Lange, 1992), 519-540. 
ISTIGHNA, Vol. 1, No 1, Januari 2018 P-ISSN 1979-2824

Homepage: http://e-journal.stit-islamic-village.ac.id/index.php/istighna

Aprianif

Taklif Dewasa Dini Dalam Hukum Islam

(Analisis Pubertas Prekoks dan Gifted)

pertumbuhan payudaranya). Hal ini pada akhirnya menjadikan mereka kurang percaya diri dan akan meningkatkan resiko terjadinya depresi. ${ }^{141}$

Sampai sekarang penyebab pasti dari pubertas prekoks ini masih belum diketahui. Tetapi secara umum dikatakan bahwa dalam keadaan yang jarang penyebabnya adalah karena meningkatnya produksi steroid. Peningkatan produksi steroid ini bisa terjadi karena beberapa hal. Diantaranya adalah karena meningkatnya sekresi hormon gonadotropin, penyakit intrinsik adrenal (ovarium atau testis), penyakit pada otak ataupun tumor yang menghasilkan hormon reproduksi. Selain itu faktor psikologis dan stressor lingkungan ekternal dikatakan biasanya juga cukup memberi peran. $^{142}$

Selanjutnya pubertas prekoks inipun terbagi dua, pubertas prekoks sentral dan pubertas prekoks perifer. ${ }^{143}$ Pubertas prekoks sentral adalah suatu pubertas prekoks yang disebabkan oleh aktivitas prematur dari poros hipotalamus-hipofisis-gonad. Maksudnya, pubertas tipe ini sama seperti pubertas pada biasanya, hanya saja ia dimulai terlalu dini. Pubertas prekoks tipe ini dikatakan memiliki banyak keanehan. Salah satu alasannya adalah karena apabila dilihat pola dan langkah-langkah dalam proses pubertas ini kejadiannya, semuanya normal, sama seperti pubertas pada biasanya. Itulah mengapa sebagian ahli mengatakan bahwa sebagian besar dari anak-anak

\footnotetext{
${ }^{141}$ Tanda-tanda seksual sekunder itu diantaranya adalah pada anak perempuan, pertumbuhan payudara, rambut di kemaluan, jerawat dan menstruasi. Untuk anak laki-laki tanda-tandanya adalah pembesaran testis dan penis, rambut di kemaluan dan ketiak, suara yang dalam dan jerawat. Apabila tanda-tanda ini muncul sebelum umur 8 tahun pada anak perempuan dan umur 9 tahun pada anak laki-laki, maka bisa disimpulkan bahwa anak tersebut terkena gejala pubertas prekoks. Batasan umur dalam pubertas prekoks ini sebenarnya sudah disandarkan pada awitan pubertas pada populasi normal. Tentu dengan sudah mempertimbangkan berbagai hal seperti ras, jenis kelamin, kondisi nutrisi, dan secular trend. Lihat Jose RL Batubara, Gonadothropin-releasing hormone agonist as a treatment of choice for central precocious puberty, Pediatric Endocrinology, Pediatric Department FKUI - RSCM, Jakarta, November 2004, Vol 19, No 4

${ }^{142}$ Haslam RHA, Endokrine System, Dalam Behrman RE, Kliegman RM, Jenson HB, Nelson Textbook of Pediatrics, Edisi XXVII (Philadelphia: Saunders Elsevier Science, 2004), 1926-1935.

${ }^{143}$ Aman B Pulungan, Pubertas dan Gangguannya, Dalam RL. Jose Batubara, Bambang Triadjaja, Aman B Pulungan Buku Ajar Endokrinologi Anak, 85-104. Lihat juga R Anwar, Sintesis, Fungsi dan Interpretasi Pemeriksaan Hormon Reproduksi, Sub Bagian Fertilitas dan Endokrinologi Reproduksi Bagian Obstetri dan Ginekologi, Fakultas Kedokteran UNPAD, Bandung 2005.
} 
ISTIGHNA, Vol. 1, No 1, Januari 2018 P-ISSN 1979-2824

Homepage: http://e-journal.stit-islamic-village.ac.id/index.php/istighna

Aprianif

Taklif Dewasa Dini Dalam Hukum Islam

(Analisis Pubertas Prekoks dan Gifted)

yang menderita pubertas prekoks tipe ini, tidak ada masalah medis yang mendasarinya dan tidak ada alasan yang dapat diidentifikasikan untuknya. ${ }^{144}$

Selain keanehan tersebut terdapat pula keanehan lainnya yaitu apabila diukur konsentrasi gonadotropin dan steroid seks serum pada penderitanya disaat pascapubertas, maka ia biasanya akan berada pada kisaran normal. Jadi karena itu dikatakan, pubertas prekoks sentral ini letak masalahnya hanya satu yaitu karena ia muncul lebih awal dari biasanya, namun urutan kronologisnya normal. Pubertas prekoks tipe ini dikenal juga dengan nama pubertas prekoks lengkap atau pubertas prekoks sejati.

Sedangkan pubertas prekoks perifer adalah kebalikannya. Bila pubertas prekoks sentral adalah pubertas prekoks yang disebabkan oleh poros hipotalamus-hipofisis-gonad, maka pada pubertas prekoks perifer, ia sama sekali tidak disebabkan oleh poros hipotalamus-hipfisis-gonad. Ia terjadi tanpa keterlibatan dari hormon Gn-RH. Padahal hormon Gn-RH adalah pemicu awal dari terjadinya pubertas. ${ }^{145}$

Penyebab dari pubertas prekoks perifer ini dikatakan rata-rata adalah karena sekresi estrogen ovarium atau adrenal pada anak perempuan dan sekresi androgen testis atau adrenal pada anak laki-laki. Pada anak perempuan, ia biasanya disebabkan oleh karena adanya kista ovarium yang berfungsi secara otonom. Dimana jika kista ovarium ini dibiarkan maka ia bisa menjadi tumor ovarium. Pada anak laki-laki biasanya ia disebabkan oleh karena sekresi androgen yang berlebihan. Kelebihan androgen pada anak laki-laki ini biasanya disebabkan karena adanya tumor sel Leydig yang menghasilkan testosterone. Tetapi walapun begitu pubertas prekoks perifer ini biasanya jarang terjadi pada anak laki-laki. ${ }^{146}$ Pubertas prekoks perifer

\footnotetext{
${ }^{144} \mathrm{R}$ Anwar, Sintesis, Fungsi dan Interpretasi Pemeriksaan Hormon Reproduksi, Sub Bagian Fertilitas dan Endokrinologi Reproduksi Bagian Obstetri dan Ginekologi, Fakultas Kedokteran UNPAD, Bandung 2005.

${ }^{145}$ JL Fahmi, JK Kaminsky, F Kaufman, MD Nelson, MT Parisi, The Radiological Approach to Precocious Puberty, The British Journal of Radiology, Vol 73, 560-567, 2000. Lihat http://bjr.birjournals.org/cgi/reprint/73/869/560.pdf

${ }^{146}$ Andrew Muir, Endrocrinolgy: Precocious Puberty, Pediatric in Revium, New York 2006.

Selanjutnya secara umum dikatakan ada beberapa hal yang dapat menyebabkan terjadinya pubertas prekoks perifer pada anak laki-laki dan perempuan. Ia adalah (1) Tumor di kelenjar
} 
ISTIGHNA, Vol. 1, No 1, Januari 2018 P-ISSN 1979-2824

Homepage: http://e-journal.stit-islamic-village.ac.id/index.php/istighna

Aprianif

Taklif Dewasa Dini Dalam Hukum Islam (Analisis Pubertas Prekoks dan Gifted)

ini dikenal juga dengan sebutan pubertas prekoks tidak lengkap atau pubertas prekoks semu. Ia merupakan jenis pubertas prekoks yang kurang umum. $^{147}$

Selanjutnya untuk bisa lebih mengenali pubertas prekoks pada seseorang, maka perlu dikenali manifestasi klinisnya. ${ }^{148}$ Apabila tanda-tanda klinis ini terjadi pada anak perempuan ataupun anak laki-laki dan dialami pada usia kurang dari 9 tahun pada anak perempuan dan usia 10 tahun pada anak laki-laki, maka bisa jadi mereka terjangkit gejala pubertas prekoks. Tanda-tanda klinisnya pada anak perempuan adalah:

a. Payudara membesar.

b. Tumbuhnya rambut pubis.

c. Tumbuhnya rambut tipis pada lengan bawah.

d. Bertambahnya tinggi dengan cepat.

e. Munculnya menstruasi.

f. Tumbuhnya jerawat dan terakhir.

g. Munculnya bau badan.

Sedangkan pada anak laki-laki, manifestasi klinisnya adalah:

a. Mengalami pembesaran testis dan penis.

b. Tumbuhnya rambut pubis.

c. Tumbuhnya rambut di lengan bawah dan wajah.

d. Peningkatan tinggi badan dengan cepat.

e. Suara mulai memberat.

f. Tumbuhnya jerawat dan,

adrenal atau kelenjar pituari yang mengeluarkan estrogen atau testosterone, (2) Sindrom McCuneAlbright dan (3) Paparan terhadap sumber eksternal dari estrogen atau testosteron, seperti krim atau salep. Sedangkan yang khusus pada anak perempuan saja adalah (1) Kista ovarium dan (2) Tumor ovarium. Selanjutnya yang khusus pada anak laki-laki adalah (1) Tumor di sel-sel yang membuat sperma (sel germinal) atau dalam sel-sel yang membuat testosteron (sel Leydig), (2) Mutasi gen yaitu sebuah gangguan langka yang disebut familial gonadotropin-independen prekositas seksual. Ia biasanya didapat karena adanya cacat pada gen. Mutasi gen ini biasanya bisa menghasilkan produksi testosterone yang lebih awal pada anak laki-laki. Biasanya antara usia 1 sampai 4 tahun. Lihat JC Carel, J Leger, Clinical Practice Precocius Puberty, 358 (22), 2366. Dalam, 93-98.

${ }^{147}$ B Setiyohadi, Kesehatan Remaja, Dalam Aru W Sudoyo, dkk, Buku Ajar Ilmu Penyakit

${ }^{148}$ Paul B Kaplowitz, Precocius Puberty, Medscape Team of Medician, diakses 2 September 2015. Lihat http://emedicine.medscape.com/article/924002-overview 
ISTIGHNA, Vol. 1, No 1, Januari 2018 P-ISSN 1979-2824

Homepage: http://e-journal.stit-islamic-village.ac.id/index.php/istighna

Aprianif

Taklif Dewasa Dini Dalam Hukum Islam

(Analisis Pubertas Prekoks dan Gifted)

g. Munculnya bau badan. ${ }^{149}$

Kemudian kelainan lain dalam pubertas adalah pubertas tarda atau pubertas terlambat. Pubertas dikatakan sebagai pubertas tarda apabila perubahan fisik awal pubertas seseorang anak belum juga terlihat padahal usianya sudah mencapai 13 tahun pada anak perempuan ataupun 14 tahun pada anak laki-laki. Jika hal ini terjadi, maka kemungkinan anak tersebut mendapatkan gejala keterlambatan pubertas atau pubertas tarda cukup besar, walaupun memang untuk memastikannya perlu tinjauan dan pemeriksaan lebih lanjut.

Sebenarnya untuk menentukan apakah seorang anak mengalami keterlambatan pubertas, ini sedikit agak rumit. Sebabnya adalah karena luasnya variasi dari perkembangan hormon manusia. Contohnya begini, di Amerika Serikat umpamanya anak perempuan hampir semuanya mengalami masa pubertas di usia 13 tahun. Kemudian ternyata ada salah seorang dari mereka yang mendapati masa pubertasnya di usia 17 tahun. Maka anak ini tidak bisa divonis lansung telah mengalami gejala keterlambatan pubertas, bisa jadi ia hanya memiliki sedikit masalah spesifik dan itu merupakan hal

${ }^{149}$ Selain dua tipe pubertas prekoks diatas, sebenarnya adalagi pubertas prekoks yang lain yaitu pubertas prekoks parsial. Pubertas prekoks parsial adalah sebuah pubertas yang mana gejala pubertasnya terjadi antara usia 6 bulan sampai 3 tahun. Pada anak perempuan bisa dikenali dengan terjadinya pembesaran payudara pada usia dibawah 3 tahun dan selanjutnya pembesarannya akan berhenti atau akan tetap bertahan seperti itu tanpa perubahan fisik. Tetapi pubertas tipe ini jarang terjadi, makanya tidak dimasukkan kedalam kategori pubertas prekoks. Lihat Paul B Kaplowitz, Precocius Puberty, Medscape Team of Medician, diakses 3 September 2015. Lihat http://emedicine.medscape.com/article/924002-overview.

Selanjutnya ada juga yang menyebut pubertas prekoks parsial ini dengan telars premature, walaupun sebenarnya tidaklah sama. Telars premature pertama kali disebutkan oleh Wilkins untuk payudara yang berkembang saja di usia di bawah tiga tahun tampa ada tanda-tanda pubertas lainnya. Kata Wilkins perkembangan payudara ini bisa di salah satunya, atau kedua-duanya. Dikatakan antara tahun 1945-1975 di Amerika Utara dilaporkan terdapat 205 kasus telars premature. Selanjutnya pada tahun 1981 di Puer to Rico dikatakan telah terjadi 482 kasus telars premature. Rogriguez mengatakan itu semua terjadi akibat mengkosumsi makanan dan minuman berupa daging ayam, sapi, babi dan susu yang mengandung preparat estrogen. Selanjutnya di Sub bagian Endokrinologi Anak dan Remaja FKUI/RSCM dari tahun 1987-1991 tercatat ada 682 kasus endoktri dan 53-nya dikatakan adalah kasus telars premature. Lihat Lihat R Roman, MC Jhonson, E Codner, MA Boric, A Avila, F Cassoria, Activating GNAS gene Metation in Patient Wich Premature Telars, J Pediatr, 2004, 145: h. 1-8. Lihat juga Saenz de Rogdriguez, AM Bongiovanni, Conde de Borrego, Epedemic of Precocius Development in Puerto Rican Children, J Pediart, 1985, 107: 393-396, dan lihat juga MS Assin, Peranan Hormon Dalam Proses Tumbuh Kembang Anak dan Remaja, Pidato Pengukuhan Penerimaan Jabatan Guru Besar Tetap Dalam Ilmu Kesehatan Anak Pada Universitas Indonesia, Jakarta, 9 Januari 1993 
ISTIGHNA, Vol. 1, No 1, Januari 2018 P-ISSN 1979-2824

Homepage: http://e-journal.stit-islamic-village.ac.id/index.php/istighna

Aprianif

Taklif Dewasa Dini Dalam Hukum Islam

(Analisis Pubertas Prekoks dan Gifted)

yang normal. Karena itulah makanya dikatakan masalah keterlambatan pubertas butuh kepada tinjauan khusus dan penelitian mendalam. ${ }^{150}$

Angka kejadian dari keterlambatan pubertas inipun sampai sekarang masih belum diketahui secara pasti. Sebabnya adalah karena tidak adanya laporan khusus dari kejadian tersebut, terutama di Indonesia. Tidak adanya laporan ini memang karena banyak dari kasus keterlambatan pubertas itu tidak pernah dilaporkan. Namun walaupun begitu secara statistik dikatakan bahwa sebanyak 2,5\% dari populasi remaja biasanya mengalami keterlambatan pubertas dan keterlambatan pubertas ini lebih banyak terjadi pada anak laki-laki dibandingkan anak perempuan. ${ }^{151}$

\section{Mengenal Anak Gifted dan Perkembangannya}

Dalam sistem perkembangan remaja selain fenomena pubertas prekoks, sebenarnya ada fenomena lain yang cukup menarik untuk dikaji, ia adalah fenomena anak gifted atau anak berbakat. Hampir sama dengan anak pubertas prekoks anak gifted ini pola perkembangannya berbeda dengan anak normal. Bila anak pubertas prekoks perbedaannya dengan anak normal karena tumbuh kembangnya yang muncul lebih awal, maka anak gifted ini tumbuh kembangnya tidak muncul lebih awal tetapi tumbuh kembangnya sering keluar dari tumbuh kembang yang biasa. ${ }^{152}$ Tumbuh kembangnya susah untuk ditebak. Kadang-kadang ia mempunyai loncatan perkembangan dengan skala besar, kadang-kadang waktunya singkat (lebih cepat) dan kadang-kadang tumbuh kembangnya tidak sinkron. ${ }^{153}$ Selain alasan itu fenomena anak gifted menarik untuk dikaji menurut hemat penulis adalah karena kebanyakan orang kurang mengetahui pola perkembangan dari anak

${ }^{150}$ Leon Speroff, Robert H Glas, Nathan G Kase, Clinical Gynecologic Endocrinology and Infertility, Edisi V (New York: Wlliams \& Wilkins, 1999), h. 88-361

${ }^{151}$ Walaupun dikatakan bahwa hampir $2,5 \%$ dari populasi remaja mengalami gejala keterlambatan pubertas, tetapi kebanyakan dari keterlambatan pubertas ini biasanya masih dalam ukuran normal atau kalau dalam bahasa kedokterannya disebut dengan CDGP (Constitutional Delay in Growth and Puberty). Lihat WB Suryawan, Pubertas Terlambat. Dalam Soetjiningsih, Tumbuh Kembang Anak dan Permasalahannya (Jakarta: Sagung Seto, 2010), h. 67-71

${ }_{152}$ Agnes Tri Harjaningrum, Dkk, Peranan Orang Tua Dan Praktisi Dalam Membantu Tumbuh Kembang Anak Berbakat Melalui Pemahaman Teori Dan Tren Pendidikan (Jakarta: Prenada Media Group, 2007), h. 116

${ }^{153}$ E Van Gerven, Zicht op Hoogbegaafdheid, Handbook Voor Leerkrachten in Het Basionderwijs (Utrecht: Uitgevij Lemma BV, 2001), h. 209-276 
ISTIGHNA, Vol. 1, No 1, Januari 2018 P-ISSN 1979-2824

Homepage: http://e-journal.stit-islamic-village.ac.id/index.php/istighna

Aprianif

Taklif Dewasa Dini Dalam Hukum Islam

(Analisis Pubertas Prekoks dan Gifted)

ini. Karena memang pola perkembangan anak yang satu ini sering tidak dibicarakan dalam deteksi perkembangan remaja. ${ }^{154}$

Berbicara mengenai gifted, ia secara bahasa berasal dari bahasa Inggris yang artinya adalah keberbakatan. Dalam bahasa Belanda ia disebut dengan Hoogbegaafd. Artinya sama saja yaitu keberbakatan atau seseorang yang mempunyai potensi yang tinggi. Secara maknawi menurut Renzulli (seorang ahli anak berbakat dari Amerika) mengatakan bahwa gifted itu adalah sesuatu yang ditujukan untuk seseorang yang mempunyai intelegensi yang tinggi diatas rata-rata (di atas skor 130), mempunyai kreativitas tinggi, serta motivasi dan komitmen kerja yang juga tinggi. ${ }^{155}$

Inilah pengertian gifted yang ketika pertama kali dikemukakan oleh Renzulli dipakai oleh hampir seluruh ahli anak gifted diseluruh belahan dunia. Teori ini dikenal dengan nama teori tiga cincin Renzulli. Namun seiring berjalannya waktu dan mulai banyaknya penelitian tentang anak gifted ini, pengertian Renzulli ini dirasa kurang. Akhirnya pengertian ini disempurnakan oleh FJ Monk (Seorang psikolog pendidikan dari Belanda yang menspelisiasikan diri pada anak gifted). Menurut FJ Monk, potensi keberbakatan seseorang seperti yang disebutkan oleh Renzulli dalam pengertian gifted di muka, apabila tidak mendapatkan dukungan yang memadai dari lingkungan, keluarga dan sekolahnya, maka keberbakatan (giftedness) itu akan sia-sia. Ia akan sulit terwujud. Karena itu menurut FJ Monk keberbakatan seseorang, kepintaran, intelegensi yang tinggi, kreatifitas dan komitmen kerja yang juga tinggi itu tidak akan berarti apaapa jika tidak didukung oleh lingkungan dan orang-orang disekitar si-gifted itu berada. Inilah pengertian gifted yang sekarang dijadikan sebagai teori

154 Julia Maria van Tiel, Anakku Terlambat Bicara (Anak Berbakat dengan Disinkronitas Perkembangan: Memahami, Mengasuhnya, Membedakannya dengan Autisme, ADHD, dan Permasalahan Gangguang Belajar), Edisi I, Cet II (Jakarta: Prenada Media Group, 2008), h. 4-5, h. 143-147.

${ }^{155}$ Renzulli, "What Makes Giftednees: A Reexamination of the Definition of the Gifted and Talented", California, Ventura Cauntry Superintendent Schools Office, 1979 
ISTIGHNA, Vol. 1, No 1, Januari 2018 P-ISSN 1979-2824

Homepage: http://e-journal.stit-islamic-village.ac.id/index.php/istighna

Aprianif

Taklif Dewasa Dini Dalam Hukum Islam (Analisis Pubertas Prekoks dan Gifted)

dasar dalam pendidikan anak gifted.Teori ini dikenal dengan istilah Triadik Renzulli-Monks. ${ }^{156}$

Sebenarnya jika mau membaca, ada banyak pengertian dari kata gifted ini, terutama tentang pengertian anak gifted. Tetapi bila diperhatikan, semuanya hampir sama, tidak jauh berbeda. Lihat apa yang dikatakan oleh Daniel P Hallahan dan James M Kauffman tentang anak gifted. Ia mengemukakan "Besides the word gifted a variety of other terms have be en used to describ individuals who are superior in some way: talented, creative, genius, and precocious, for example". Anak gifted itu adalah anakanak yang mempunyai talenta yang besar, kreativitas tinggi, sangat jenius dan mungkin bisa dikatakan dewasa sebelum waktunya. ${ }^{157}$ Atau seperti yang dikatakan oleh David G Amstrong dan Tom V Savage mengutip Public Law 91-230 (United States Statutes tahun 1971) "gifted and talented children" mean, in accordance with objective criteria prescribed by the commissioner, children who hav outstanding intelectual ability or creative talent, the development of which requires special activities or services not ordinarily provided by local educational agencies". Anak gifted dan anak bertalenta adalah anak-anak yang mempunyai kemampuan intelektual yang luar biasa serta bakat dan kreatifitas, karena itu pengembangannya yang membutuhkan kepada kegiatan dan pelayanan yang tidak biasa akan disedikan oleh lembaga pendidikan yang khusus. ${ }^{158}$ Ataupun apa yang disampaikan oleh LJ Coleman dalam bukunya Scholling the Gifted. Ia mengemukakan bahwa anak gifted secara konvensional adalah anak yang tingkat intelensianya diatas rata-rata kelompoknya, IQ-nya lebih dari $120{ }^{159}$

156 Julia Maria van Tiel, Anakku Terlambat Bicara (Anak Berbakat dengan Disinkronitas Perkembangan: Memahami, Mengasuhnya, Membedakannya dengan Autisme, ADHD, dan Permasalahan Gangguang Belajar), h. 5

${ }^{157}$ Daniel P Hallahan, James M Kauffman, Exceptional Children Introduction to Special Education (New York: Prentice-Hall Inc, 1982), h. 376

${ }^{158}$ David G Amstrong, Tom V Savage, Secondary Education: An Introduction, (New York: Macmillan Publishing, 1983), h. 324

${ }^{159}$ LJ Coleman, Scholling the Gifted (New York: Addison-Wesley Publishing Company, 1985), h. 284 
ISTIGHNA, Vol. 1, No 1, Januari 2018 P-ISSN 1979-2824

Homepage: http://e-journal.stit-islamic-village.ac.id/index.php/istighna

Aprianif

Taklif Dewasa Dini Dalam Hukum Islam

(Analisis Pubertas Prekoks dan Gifted)

Jadi intinya dapat disimpulkan bahwa seorang anak gifted itu tidak bisa hanya dilihat dari tingginya hasil tes intelegensianya saja, tetapi ia juga harus diikuti oleh beberapa faktor lain berupa kreativitas, motivasi dan komitmen. Tidak hanya itu ia juga harus mendapatkan berbagai dukungan dari lingkungan, sekolah dan juga keluarganya. Semua itulah yang pada akhirnya akan menentukan berhasil atau tidaknya seorang anak gifted dalam mencapai prestasi yang ia ingingkan. Oleh karena itu para ahli keberbakatan biasanya akan selalu menekankan pendekatan Nature (potensi bawaan) dan Nurture (pengaruh lingkungan). ${ }^{160}$

Istilah anak gifted ini memang agak terasa asing di Indonesia, karena memang jarang digunakan. Dia biasanya lebih dikenal dengan sebutan anak berbakat. ${ }^{161}$ Tetapi penyebutan anak berbakat untuk anak gifted sebenarnya agak kurang pas, karena biasanya kata berbakat akan sering tertukar dengan kata bertalenta. Padahal antara anak berbakat dengan anak bertalenta itu mempunyai pengertian yang berbeda. Di kalangan ilmuwan, anak bertalenta adalah apabila seorang anak mempunyai sedikitnya satu bidang yang ia

160 Agnes Tri Harjaningrum Dkk, Peranan Orang Tua Dan Praktisi Dalam Membantu Tumbuh Kembang Anak Berbakat Melalui Pemahaman Teori Dan Tren Pendidikan, h. 116

${ }^{161}$ Sutratinah Tirtonegoro dan Samsu Yusuf pernah mengemukakan bahwa anak yang mempunyai kecerdasan di atas rata-rata itu diklasifikasikan menjadi tiga kelompok, superior, gifted dan genius. Ketiga kelompok anak ini dibedakan dari peringkat ketinggian IQ yang mereka miliki.

1. Genius. Seorang anak dikatakan genius adalah ketika ia memiliki kecerdasan yang sangat luar biasa, sehingga ia dapat menciptakan sesuatu bernilai sangat tinggi. Intelligence Quotien-nya dikatakan berkisar antara 140 sampai 200. Anak genius ini biasanya memiliki sifat-sifat positif seperti punya daya abstraksinya baik sekali, mempunyai banyak ide, sangat kritis, sangat kreatif, suka menganalisis dan lain sebagainya. Di samping itu ia juga memiliki sifat-sifat negatif seperti egois, temperamen atau emosional, tidak mudah bergaul, senang menyendiri dan tidak mudah menerima pendapat orang lain.

2. Gifted. Seorang anak dikatakan gifted apabila tingkat kecerdasannya (IQ) antara 125 sampai dengan 140. Kemudian selain IQ-nya ia juga mempunyai bakat yang sangat menonjol, seperti bakat seni musik, drama, memimpin dan lain sebagainya. Anak gifted dikatakan mempunyai karakteristik suka kepada sains, serba ingin tahu, imajinasinya kuat, senang membaca dan senang mengoleksi sesuatu.

3. Superior. Seorang dikatakan superior adalah apabila tingkat kecerdasannya berkisar antara 110 sampai dengan 125 . Ia biasanya mempunyai prestasi belajarnya cukup tinggi. Karakteristiknya biasanya adalahdapat berbicara lebih dini, dapat membaca lebih awal, dapat mengerjakan pekerjaan sekolah dengan mudah dan dapat perhatian dari teman-temannya. Lihat Sutratinah Tirtonegoro, Anak Supernormal dan Program Pendidikannya, (Jakarta: Bina aksara, 1984), h. 29-33. Lihat juga Samsu Yusuf, Psikologi Perkembangan Anak dan Remaja (Bandung: Remaja Rosdakarya, 2002), h. 112 
ISTIGHNA, Vol. 1, No 1, Januari 2018 P-ISSN 1979-2824

Homepage: http://e-journal.stit-islamic-village.ac.id/index.php/istighna

Aprianif

Taklif Dewasa Dini Dalam Hukum Islam (Analisis Pubertas Prekoks dan Gifted)

kuasai secara luar biasa, misalnya bidang matematika, fisika atau lain sebagainya. Sedangkan anak gifted sebagaimana disebutkan sebelumnya, ia harus memenuhi kriteria sebagaimana yang disebutkan didalam teori Triadik Renzulli-Monks. Artinya ia harus mempunyai intelengensia yang tinggi, kreativitas tinggi serta motivasi dan komitmen kerja yang juga tinggi. Ditambahkan lagi lingkungan yang selalu mendukungnya. Sehingga dapat dipastikan bahwa anak gifted pasti akan memiliki banyak talenta. Karena itu anak berbakat (gifted children) akan sering disebut sebagai anak bertalenta karena memang ia memiliki banyak talenta di berbagai bidang. ${ }^{162}$

Selain anak bertalenta, sebenarnya masih ada istilah lain untuk anak yang sering dikait-kaitkan dengan anak berbakat, padahal ia bukanlah anak berbakat. Ia adalah anak cerdas atau yang biasa disebut dengan bright children. Menurut para ilmuwan anak-anak cerdas ini tidak bisa dimasukkan kedalam kelompok anak berbakat (gifted children), karena diantara keduanya mempunyai karakteristik yang berbeda. Walaupun sebenarnya mereka sama-sama mempunyai intelegensia yang tinggi, namun pada beberapa faktor mereka berbeda seperti kemampuan analisis, abstraktif dan kreativitas. Sejatinya pastinya anak cerdas tidaklah seluar biasa anak berbakat. $^{163}$

Tetapi selanjutnya anak gifted ini acap kali disebut-sebut oleh ahli kependidikan anak berbakat sering mengalami masalah disinkronitas yaitu suatu masalah yang sering menyebabkan perkembangannya terganggu. Disikronitas ini bisa meliputi antara fisik dan psikisnya dan bisa juga antara perkembangan sosial dan kognitifnya. Banyak diantara anak-anak gifted ini yang pada usia dini sudah membaca banyak buku, berfikir jauh ke depan dan lain sebagainya. Sehingga dengan sendirinya, mereka yang sering membaca buku tersebut akan terdapat ketidak harmonisan antara

162 Julia Maria van Tiel, Anakku Terlambat Bicara (Anak Berbakat dengan Disinkronitas Perkembangan: Memahami, Mengasuhnya, Membedakannya dengan Autisme, ADHD, dan Permasalahan Gangguang Belajar), h. 6

${ }^{163}$ Kurt A Heller, Identification of Gifted and Talented Students, Psychology Science, Volume 46, 2004 (3), h. 302-323. Prof. Dr. Kurt A Huller adalah guru besar Department of Psychology University of Munich. 
ISTIGHNA, Vol. 1, No 1, Januari 2018 P-ISSN 1979-2824

Homepage: http://e-journal.stit-islamic-village.ac.id/index.php/istighna

Aprianif

Taklif Dewasa Dini Dalam Hukum Islam (Analisis Pubertas Prekoks dan Gifted)

perkembangan mentalnya dengan umur kronoligisnya. Akhirnya Anak-anak yang terbiasa mengembangkan bakat intelektualnya ini akan merasa cocok dan lebih suka bergaul dan berbicara dengan orang-orang yang lebih tua dari mereka. Disinilah kadang ketidak seimbangan faktor usia sering terjadi. Oleh karena itu, maka tidaklah mengherankan jika banyak diantara mereka yang karena bakat intelektualitasnya dikembangkan dengan sangat baik, ia dapat melanjutkan pendidikannya ke jenjang perguruan tinggi di usia yang sangat muda. ${ }^{164}$

\section{Antara Konsep Taklif Dewasa Dini dan Ijtihad Intiqa'i}

Sebagaimana diketahui bersama di dalam terminologi hukum Islam, ada sebuah istilah yang biasa disebut dengan al-mukallaf (yang dibebani hukum) atau dalam istilah lain al-mahkum 'alaih (subjek hukum) yaitu seseorang yang telah dianggap mampu bertindak secara hukum. ${ }^{165}$ Maksudnya adalah apabila seseorang telah mendapatkan prediket mukallaf atau mahkum 'alaihi ini, maka ia sudah harus mempertanggungjawabkan segala perbuatannya di hadapan hukum. ${ }^{166}$

${ }^{164}$ Masalah disinkronitas ini sebenarnya sudah diketahui dari sejak lama. Dulu sekitar tahun 1964 seorang psikiater klinik dari Polandia yang bernama Kazimiers Dabrowski pernah mengutarakan masalah ini. Masalah disikronitas ini juga pernah dimasukkan oleh Jean Charles Terrasier pada tahun 1972 ke dalam pembahasan bidang psikologi di kelompok anak-anak gifted. Jadi masalah disinkronitas ini sebenarnya sudah diketahui dari masa yang lama. Namun masalahnya sejauh ini, karena personalitas dan karakteristik tumbuh kembang anak gifted cukup jarang dilakukan peneletian, maka pengetahuan tentang masalah itu (tumbuh kembang anak-anak gifted yang ternya dapat mengalami disinkronitas perkembangan) masih minim sekali. Selama ini anak gifted yang kita kenal adalah anak-anak yang tidak mempunyai masalah, baik masalah tumbuh kembangnya ataupun masalah perilakunya. Kadang kalau dibaca banyak buku, maka justru para ahli anak berbakat mengatakan, semakin tinggi perkembangan intelegensia seorang anak, maka anak tersebut akan semakin besar mengalami efek dari ekstremitasnya berupa gangguan fisik, psikis, motorik, sosial, emosional dan prilakunya. Seorang psikolog dari Amerika yang sekarang menjadi direktur dari Gifted Center Colorado Linda Silverman pernah mengutarakan masalah ini, ia mengistilahkan ketidaksinkronan anak-anak gifted ini dengan istilah asynchronous development of gifted children. Lihat Agnes Tri Harjaningrum Dkk, Peranan Orang Tua Dan Praktisi Dalam Membantu Tumbuh Kembang Anak Berbakat Melalui Pemahaman Teori Dan Tren Pendidikan, h. 124

${ }^{165}$ Abuddin Nata, Abdur Rahman Dahlan, Muhammad Amin Suma, Ahmad Thib Raya dan kawan-kawan, Ensiklopedi Hukum Islam (Jakarta: Ichtiar Baru Van Hoeve, 1999), h. 1219

${ }^{166}$ Muhammad Ibn Ali Ibn Muhammad ash-Syaukani, Irshad al-Fuhul ila Tahqiq al-Haq min 'Ilmi al-Usul (Cairo: Dar as-Salam, 2006), h. 65. Lihat juga Teguh Prasetyo dan Abdul Halim Barkatullah, Politik Hukum Pidana (Yogyakarta: Pustaka Pelajar, 2005), h. 135-136 
ISTIGHNA, Vol. 1, No 1, Januari 2018 P-ISSN 1979-2824

Homepage: http://e-journal.stit-islamic-village.ac.id/index.php/istighna

Aprianif

Taklif Dewasa Dini Dalam Hukum Islam

(Analisis Pubertas Prekoks dan Gifted)

Lalu apa patokan yang dijadikan dasar oleh hukum Islam untuk mengetahui apakah seseorang tersebut sudah mukallaf atau belum. Untuk mengetahui ini perlu dipahami bahwa sebenarnya dalam hukum Islam, prinsipnya ialah ia tidak mau mengenakan pembebanan hukum kepada seseorang sebelum seseorang tersebut mengerti dan paham akan hukum yang diberlakukan kepadanya. Oleh karena itu, di dalam hukum Islam itu ada sebuah ketentuan dasar yaitu fahm al-mukallaf lima kullifa bihi, artinya pengetahuan atau pemahaman subjek hukum terhadap suatu hukum yang diberlakukan kepadanya menjadi sarat utama sebelum ia mempertanggungjawabkannya. ${ }^{167}$

Kemudian selanjutnya bagaimana cara mengetahui bahwa seseorang itu sudah mempunyai fahm al-mukallaf lima kullifa bihi. Jawabannya adalah seseorang bisa dikatakan sudah mempunyai fahm al-mukallaf lima kullifa bihi, apabila ia telah memenuhi beberapa ketentuan yaitu 'aqil (berakal sehat), balig (cukup umur) dan mumayyiz (dapat membedakan baik dan buruk). ${ }^{168}$ Ketika seseorang belum 'aqil, belum balig dan belum mumayyiz, maka biasanya pemahamannya terhadap suatu hukum, belumlah benar-benar sempurna.

Selain itu, seseorang juga belum akan dikenakan pembebanan hukum dalam hukum Islam sebelum ia mendapatkan prediket kelayakan dan kecakapan (capability and capacity). ${ }^{169}$ Kelayakan dan kecakapan ini di dalam terminologi hukum Islam dikenal dengan istilah al-Ahliyah. Al-ahliyah itu adalah suatu sifat yang dimiliki oleh seseorang yang dijadikan ukuran oleh syari' (Allah Swt) untuk menentukan apakah ia telah cakap dikenai tuntutan syara' atau belum. ${ }^{170}$ Dalam pengertian lain ia diartikan dengan suatu sifat yang menunjukkan bahwa seseorang telah sempurna jasmani dan akalnya, sehingga secara hukum seluruh tindakannya sudah dapat dipertanggungjawabkannya. ${ }^{171}$

${ }^{167}$ Ash-Shaukani, Irshad al-Fuhul ila Tahqiq al-Haq min 'Ilmi al-Usul, h. 65

${ }^{168}$ Wahbah az-Zuhayli, al-Fiqh al-Islami wa Adillatuh, Juz IV (Beirut: Dar al-Fikr, 1989), h. 121

169 Abdul Hay 'Azb Abdul 'Al, Usul al-Fiqh al-Muyassar, Cet II (Cairo: Universitas Al Azhar, 2006), h. 183

${ }^{170}$ Abuddin Nata, Abdur Rahman Dahlan, Muhammad Amin Suma, Ahmad Thib Raya dan kawan-kawan, Ensiklopedi Hukum Islam, h. 1220

${ }^{171}$ Abdul Aziz al-Bukhari, Kashf al-Asrar, Jilid II (Beirut: Dar al-Fikr, 1982), h. 1357 
ISTIGHNA, Vol. 1, No 1, Januari 2018 P-ISSN 1979-2824

Homepage: http://e-journal.stit-islamic-village.ac.id/index.php/istighna

Aprianif

Taklif Dewasa Dini Dalam Hukum Islam

(Analisis Pubertas Prekoks dan Gifted)

Konsep al-ahliyah ini di dalam ilmu Usul Fiqh itu diklasifikasikan menjadi dua, yaitu al-Ahliyah al-Ada' dan al-Ahliyah al-Wujub. Al-Ahliyah al-Ada' adalah suatu sifat kecakapan bertindak hukum seseorang yang telah dianggap sempurna untuk bisa mempertanggungjawabkan seluruh perbuatannya, baik itu yang bersifat positif ataupun negatif. Wazn atau ukuran dalam al-Ahliyah al-Ada' ini adalah aqil, baligh dan berakal sempurna. Sedangkan al-Ahliyah al-Wujub adalah sifat kecakapan seseorang untuk menerima hak-hak yang menjadi haknya walaupun ia belum cakap untuk dibebani kewajiban hukum. Ia hanya dianggap mampu untuk menerima hak-haknya dan tidak dituntut adanya kewajiban hukum atas dirinya. ${ }^{172}$

Oleh karena itu, ulama Usul Fiqh (ahli hukum Islam) mengemukakan bahwa dasar pertanggungjawaban hukum dalam hukum Islam itu ringkasnya hanya tiga saja yaitu berakal ('aqil, mumayyiz), cukup umur (baligh) dan pemahaman. Artinya seseorang baru bisa dibebani hukum apabila ia berakal, dapat memahami secara baik taklif yang ditujukan kepadanya dan ia sudah cukup umur. $^{173}$

Ketika berbicara tentang ketiga syarat ini, sebenarnya itu agak sedikit sulit dan rumit. Ketiganya sebenarnya adalah suatu hal yang tidak bisa dipisahkan antara satu dengan yang lain. Prinsipnya, pemahaman hanya bisa dicapai melalui akal yang sehat dan akal adalah sesuatu yang tersembunyi dan sulit diukur serta akan berbeda-beda antara satu orang dengan yang lainnya sesuai dengan perkembangan biologisnya. Maka karena itu, hukum Islam kemudian menetapkan patokan dasar sebagai indikasi luar dalam menentukan apakah seseorang tersebut sudah cukup berakal atau belum, sudah cukup mampu memahami syara' atau belum. Indikasi itu adalah balig (cukup umur).

Berbicara tentang balig, ulama Mazhab mempunyai pandangan yang berbeda-beda. Namun walaupun begitu rata-rata semuanya sepakat mengukurnya dengan haid bagi kaum perempuan dan keluar air mani bagi kaum laki-laki atau

${ }^{172}$ Abu Hamid al-Ghazali, al-Mustasfa fi 'Ilmu al-Usul, Jilid I (Beirut: Dar al-Kutub al'Ilmiyyah, 1983), 98. Lihat juga Muhibullah Ibn Abdush Shakur, Musallam ats-Tsubut, Jilid I (Beirut: Dar al-Kutub al-'Ilmiyah, 1983), 116.

${ }^{173}$ Abu Bakar Muhammad al-Sarakhsi, Usul al-Sarakhsi, Jilid II (Beirut: Dar al-Kutub al'Ilmiyyah, 1983), 340. Lihat juga Saifuddin al-Amidi, al-Ihkam fi Usul al-Ahkam (Beirut: Dar alKutub al-'Ilmiyyah, 1983), 137. 
ISTIGHNA, Vol. 1, No 1, Januari 2018 P-ISSN 1979-2824

Homepage: http://e-journal.stit-islamic-village.ac.id/index.php/istighna

Aprianif

Taklif Dewasa Dini Dalam Hukum Islam (Analisis Pubertas Prekoks dan Gifted)

telah genap berusia 15 tahun menurut mayoritas jumhur ulama. Kemudian mereka juga sepakat mengatakan bahwa untuk tiga batasan ini prinsip yang digunakan adalah mana yang lebih dahulu dicapai atau dipenuhi oleh si anak. ${ }^{174}$

Menurut ulama Hanafiyyah balig bagi laki-laki itu bisa dicapai dengan:

1. Keluar mani, baik dalam keadaan tidur (ihtilam) ataupun terjaga, karena bersetubuh atau bukan dan,

2. Menghamili.

Tetapi kemudian dua kriteria ini, itu harus diikuti oleh satu kriteria lainnya yaitu ia harus berusia minimal 12 tahun. Sedangkan kriteria untuk perempuan adalah:

1. Haid dan,

2. Hamil

Dengan ketentuan lainnya, mereka harus berusia minimal 9 tahun, dan seandainya karena sesuatu hal, kriteria-kriteria ini tidak muncul maka imam Abu Hanifah (w.150 H) mengatakan bahwa batasan usia yang dipakai adalah bagi laki-laki usia 18 tahun dan bagi perempuan usia 17 tahun. ${ }^{175}$

Ulama Malikiyah mengatakan bahwa kriteria balig itu ada tujuh macam. Lima bagi laki-laki dan perempuan, dua khusus bagi perempuan saja. Kriteria yang khusus bagi perempuan itu adalah:

1. Haid dan,

2. Hamil.

Sedangkan kriteria yang berlaku bagi laki-laki dan perempuan adalah:

1. Keluarnya air mani baik dalam keadaan tidur ataupun terjaga.

2. Tumbuhnya rambut kemaluan.

3. Tumbuhnya rambut ketiak.

4. Indra penciuman menjadi peka dan yang terakhir.

5. Perubahan suara.

${ }^{174}$ Abu Abdillah Muhammad Ibn Ahmad al-Qurtubi, al-Jami' li Ahkam Al-Qur'an, Jilid V (Beirut: Dar al-Fikr, t.thn), 37.

${ }^{175}$ Ibn 'Abidin, Hashiyah Rad al-Mukhtar 'ala Daur al-Mukhtar, Jilid V (Cairo: Al-Bab alHalabi, t.thn), 107. 
ISTIGHNA, Vol. 1, No 1, Januari 2018 P-ISSN 1979-2824

Homepage: http://e-journal.stit-islamic-village.ac.id/index.php/istighna

Aprianif

Taklif Dewasa Dini Dalam Hukum Islam (Analisis Pubertas Prekoks dan Gifted)

Namun apabila kriteria balig ini tidak muncul maka batasan usia yang mereka pakai adalah usia genap 18 tahun atau usia genap 17 tahun memasuki usia 18 tahun. ${ }^{176}$

Imam As-Sairazi (w.476 H) dan al-Khatib (w.977 H) mengemukakan bahwa di dalam Mazhab Syafi'i balig bagi laki-laki dan perempuan itu dapat dicapai dengan:

1. Usia anak genap 15 tahun Qomariyah.

2. Keluarnya air mani bagi laki-laki dan perempuan di usia yang memungkinkan yaitu minimal usia 9 tahun, dan

3. Tumbuhnya rambut di sekitar kemaluan.

Sedangkan kriteria balig yang khusus bagi perempuan adalah:

1. Haid, dan

2. Hamil. ${ }^{177}$

Wahbah az-Zuhayli (w.1436 H) pernah menyimpulkan, berdasar berbagai pendapat para ulama Mazhab diatas, menurut pengamatan beliau kriteria balig itu sejatinya hanya ada lima saja. Tiga untuk laki-laki dan perempuan, dua khusus untuk perempuan. Tiga untuk laki-laki dan perempuan itu adalah:

1. Keluarnya air mani.

2. Tumbuhnya rambut kemaluan, dan

3. Batasan usia tertentu.

Sedangkan yang khusus untuk perempuan saja adalah:

1. Haid, dan

2. Hamil. ${ }^{178}$

Dalil-dalil yang dipakai dalam masalah balig ini diantaranya adalah surat an-Nur (24) ayat 59,

${ }^{176}$ Ad-Dardiri, Al-Sharah al-Kabir Hashiyah Dasuki, Jilid III (Cairo: Matba'ah al-Bab alHalabi, t.thn), 293.

${ }^{177}$ Abu Ishak as-Sairazi, Al-Muhadhdhab, Juz I (Cairo: Mathba'ah al-Bab al-Halabi, t.thn), 330. Lihat juga ash-Sharbini al-Khatib, Mughni al-Muhtaj Sharah al-Minhaj, Juz II (Cairo: Mathba'ah al-Bab al-Halabi, t.thn), 166.

${ }^{178}$ Wahbah az-Zuhayli, al-Fiqh al-Islami wa Adillatuhu, Juz V (Beirut: Dar al-Fikr, 1989), 424. 


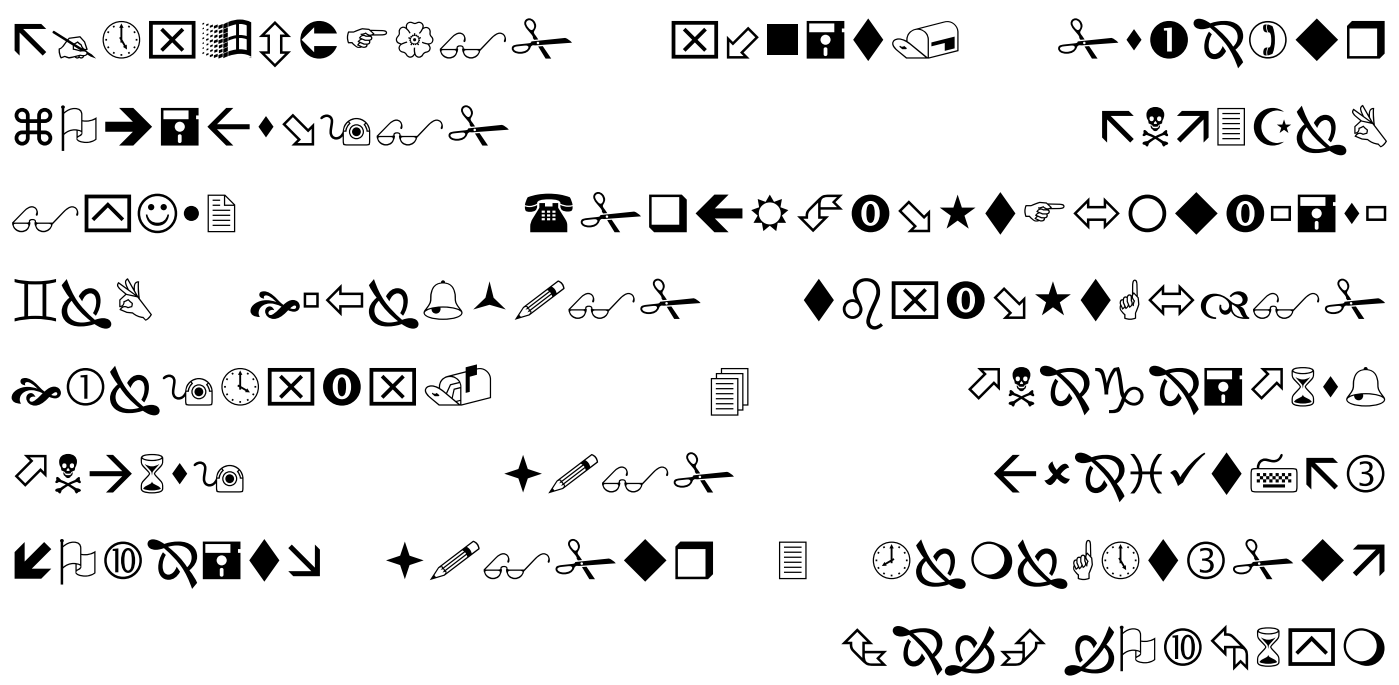

Artinya: "Dan apabila anak-anakmu telah sampai usia balig, maka hendaklah mereka meminta izin, seperti orang-orang yang sebelum mereka meminta izin. Demikianlah Allah menjelaskan ayat-ayat-Nya dan Allah Maha mengetahui lagi Maha Bijaksana”.

Kemudian Hadis dari Ibn Umar Ra,

عرضني رسول الله صلي الله عليه و سلم يوم احد في القتال, و انا ابن اربع عشرة سنة, فلم يجزني, و عرضني يوم الخندق, و انا ابن خمسة عشرة سنة, فاجازني, قال نافع: فقدمت علي عمر بن عبد الغزيز و هو يومئذ خليفة, فحدثته هذا الحديث, فقال: ان هذا لحد بين الصغير و الكبير. 179

Artinya: "Rasulullah Saw menunjukku untuk ikut serta dalam perang Uhud yang ketika itu usiaku empat belas tahun, namun beliau tidak memperbolehkanku, dan kemudian beliau kembali menunjukku pada perang khandak yang ketika itu usiaku lima belas tahun, beliaupun memperbolehkanku. Nafi' (perawi hadith ini) berkata: "Aku menghadap Umar Ibn Abdul Aziz (w.101 H) pada saat itu beliau menjabat sebagai khalifah, kemudian aku menceritakan hadis ini, lalu Umar Ibn Abdul Aziz berkata: Sesungguhnya ini adalah batas antara orang yang masih kecil dan sudah dewasa".

${ }^{179}$ Abu Zakariya Muhyuddin An-Nawawi, Sahih Muslim bi Sharah An-Nawawi, Juz XIII (Beirut: Darul Khair, 1994) 12. 
ISTIGHNA, Vol. 1, No 1, Januari 2018 P-ISSN 1979-2824

Homepage: http://e-journal.stit-islamic-village.ac.id/index.php/istighna

Ada juga hadis dari Sayyidah Aishah Ra (w.58 H),

$$
\text { لا يقبل الله صلاة امر اة قد حاضت الا بخمار } 180
$$

Artinya: "Allah Swt tidak menerima salat seorang perempuan yang telah haid kecuali dengan berkurudung." (Hadis riwayat Ibn Huzaimah dan atTirmidhi).

Kemudian ada juga hadis yang sangat populer dari Sayyidah Aishah Ra juga,

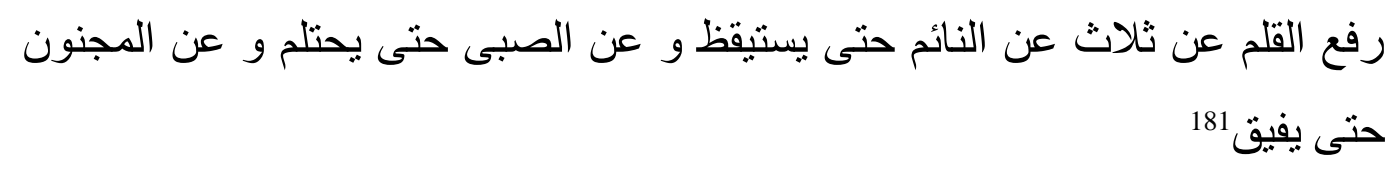

Artinya: "Diangkatlah (dihilangkanlah) pembebanan hukum dari tiga (kategori orang), yaitu orang tidur sampai ia bangun, anak kecil sampai ia balig dan orang gila sampai ia sembuh". (Hadits riwayat Bukhari, Abu Dawud, at-Tirmidhi, an-Nasai, dan Ibn Majah dari Aisyah dan 'Ali Ibn Abi Talib Radiyallahu 'anhuma).

Melihat kepada semua dalil-dalil ini, maka jelas tanda balig itu adalah keluarnya air mani kali pertama bagi anak laki-laki dan keluarnya haid kali pertama bagi anak perempuan, dan jika seandainya anak laki-laki tersebut tidak keluar air mani ataupun anak perempuan tersebut tidak keluar haid, maka batasan usianya adalah usia genap 15 tahun. Begitu yang disepakati oleh jumhur ulama.

Pertanyaannya adalah mungkinkah konsep taklif ini diberlakukan untuk anak-anak pubertas prekoks dan gifted. Untuk anak-anak gifted mungkin tidak begitu bermasalah, tetapi untuk anak-anak pubertas prekoks ini sungguh sangat kurang adil rasanya. Karena diantara mereka anak pubertas prekoks tersebut, ada yang keluar air mani ataupun haid di usia yang sangat-sangat dini, ada yang di

${ }^{180}$ Al-Hafiz at-Tirmidhi, Sunan at-Thirmidhi, Cet I, Kitab as-Salah, Hadist 337, 121. Bab جاء لا تقبل صلاة امر اة الا بخمار. Hadith ini bercerita tentang tidak sahnya salat seorang permpuan yang sudah haid, jka ia tidak berkerudung. Artinya jika seorang perempuan sudah mendapatkan haid, maka ia sudah diwajibkan salat. http://library.islamweb.net/newlibrary/display_book.php?flag=1\&bk_no=56\&ID=679

${ }^{181}$ Al-Hafiz at-Tirmidhi, Sunan at-Thirmidhi, Cet I, Kitab al-Hudud, Hadist 1423, 336. Lihat juga Jalal ad-Din as-Suyuti, Sunan an-Nasai bi Sharh al-Hafiz Jalal ad-Din as-Suyuti, Juz VI, Bab Talaq, Hadist 3432, 468. 
ISTIGHNA, Vol. 1, No 1, Januari 2018 P-ISSN 1979-2824

Homepage: http://e-journal.stit-islamic-village.ac.id/index.php/istighna

Aprianif

Taklif Dewasa Dini Dalam Hukum Islam

(Analisis Pubertas Prekoks dan Gifted)

usia 8 tahun, 7 tahun bahkan ada yang di usia 6 tahun. Rasanya tidak mungkin saja anak sekecil itu dianggap sebagai seseorang yang sudah dewasa, seseorang yang sudah mempunyai tanggungjawab dan kewajiban-kewajiban tertentu. Karena itu, menurut hemat penulis perlu kiranya dicarikan solusi untuk masalah ini, tetapi tentunya dengan melakukan ijtihad.

Menurut Yusuf al-Qardawi, ijtihad yang bisa dilakukan setidaknya ada dua, yaitu ijtihad intiqai dan ijtihad inshai. Ijtihad intiqai (ijtihad selektif) adalah suatu ijtihad yang dilakukan oleh seseorang atau sekelompok orang untuk memilih pendapat ahli Fiqh terdahulu terhadap suatu masalah tertentu sebagaimana yang terdapat dalam kitab-kitab Fiqh. Tentunya dengan menyeleksi mana pendapat yang lebih kuat dalilnya dan lebih relevan untuk diterapkan dalam kondisi sekarang ini. Dalam hal ini menurut Yusuf al-Qardawi, seorang mujtahid harus bertitik tolak pada empat hal.

1. Pendapat tersebut lebih relevan diterapkan untuk zaman sekarang.

2. Pendapat tersebut lebih banyak mencerminkan rahmat bagi umat manusia.

3. Pendapat tersebut lebih dekat kepada kemudahan yang diberikan syara'.

4. Dan pendapat tersebut lebih utama dalam merealisir maksud dan tujuantujuan syara', yaitu berupa pencapaian kemaslahatan dan menjauhi kerusakan dari umat manusia. ${ }^{182}$

Ijtihad model ini, sebenarnya bukanlah hal yang baru dalam lapangan ilmu Fiqh perkembangan. Ia dulu sering dan pernah dilakukan oleh Ibn Rusdh (w.594 H) tokoh Fiqh mazhab Maliki dalam bukunya Bidayah al-Mujtahid wa Nihayah al-Muqtasid. $^{183}$ Kemudian ada Shihabuddin al-Qarrafi (w.684 H) tokoh Fiqh madhhab Maliki juga dalam bukunya al-Furuq, dan juga ada Ibn Qudamah $($ w.620 H) tokoh Fiqh madhhab Hanbali dalam bukunya al-Mugni, walaupun memang istilah ijtihad intiqai ini baru muncul belakangan ini. ${ }^{184}$ Dikatakan ketiga

${ }^{182}$ Yusuf al-Qardawi, Al-Ijtihad Fi asy-Syari'ah al-Islamiyah Ma'a Nazarat Tahliliyah Fi Ijtihad al-Mu'asir. Diterjemahkan oleh Ahmad Syatori, Ijtihad Dalam Syari'at Islam Dan Beberapa Pandangan Analisi Tentang Ijtihad Kontemporer (Jakarta: Bulan Bintang, 1987), h. 115

${ }^{183}$ Muhammad Ibn Rushd, Bidayah al-Mujtahid wa Nihayah al-Muqtasid (Beirut: Dar alJil, 1989)

${ }^{184}$ Ahmad Ibn Qudamah, al-Mugni (Beirut: Dar Al-Kutub al-Ilmiyah, t.thn). Lihat juga Shihabuddin al-Qarrafi, al-Furuq (Beirut, Dar al-Fikr, 1982). 
ISTIGHNA, Vol. 1, No 1, Januari 2018 P-ISSN 1979-2824

Homepage: http://e-journal.stit-islamic-village.ac.id/index.php/istighna

Aprianif

Taklif Dewasa Dini Dalam Hukum Islam

(Analisis Pubertas Prekoks dan Gifted)

tokoh ini melakukan ijtihad intiqai itu disebabkan karena adanya faktor perubahan sosial yang terjadi dalam kehidupan masyarakat pada waktu itu.

Selanjutnya setelah ijtihad intiqai, ada ijtihad insyai (ijtihad kreatif). Ia adalah suatu ijtihad yang mengambil konklusi hukum baru dalam suatu permasalahan yang belum pernah dikemukakan oleh ulama Fiqh terdahulu, baik itu masalah baru ataupun masalah lama. Maksudnya adalah persoalan yang dicarikan hukumnya tersebut bisa persoalan yang benar-benar baru, artinya persoalan tersebut belum pernah ada kasusnya dan hukumnya dalam khazanah keilmuwan Fiqh klasik, ataupun terhadap persoalan lama yang sudah pernah dibahas oleh ulama terdahulu, tetapi mujtahid tersebut melakukan ijtihad dengan memunculkan pendapat yang baru diluar pendapat-pendapat yang sudah ada. Contohnya seperti suatu kasus itu memiliki tiga pendapat. Kemudian datang seorang mujtahid baru dan ia mengemukakan pendapat yang keempat. Hal ini menurut Yusuf al-Qardawi boleh, tidak dilarang didalam Islam. ${ }^{185}$

Kemudian beliau juga mengatakan bahwa dalam hal ijtihad insyai ini, terutama di zaman modern ini, untuk memahami, membahas dan meneliti kasuskasus baru yang akan ditentukan hukumnya, maka hal yang paling tepat dilakukan adalah dengan mengumpulkan berbagai ahli yang terkait dengan masalah tersebut. Dengan dikumpulkannya para ahli ini, itu akan bisa mengungkap segala seluk beluk permasalahan yang berhubungan dengan masalah tersebut. Sehingga pada akhirnya kesimpulan hukum yang diambil itu bisa lebih mendekati kebenaran. Ijtihad ini disebut dengan ijtihad jama'i. Sikap kebersamaan dalam memecahkan suatu kasus oleh berbagai ahli yang terkait. Apalagi di zaman modern ini, kemampuan seseorang itu sangat terbatas. Ditambah lagi dengan adanya

${ }^{185}$ Dalam kasus ini sebenarnya terdapat perbedaan pandangan ulama Usul Fiqh. Sebagian menyatakan bahwa jika dalam suatu kasus terdapat dua pendapat, mujtahid lain tidak boleh memunculkan pendapat ketiga. Tetapi menurut Yusuf al-Qardawi, patokannya bukanlah pendapatnya, tetapi dalil. Jika seorang mujtahid munshi' menemukan dalil yang baru, maka bisa saja ia memunculkan pendapat yang berbeda dengan pendapat yang sudah ada. Lihat Yusuf alQardawi, Al-Ijtihad Fi asy-Syari'ah al-Islamiyah Ma'a Nazarat Tahliliyah Fi Ijtihad al-Mu'asir. Diterjemahkan oleh Ahmad Syatori, Ijtihad Dalam Syari'at Islam Dan Beberapa Pandangan Analisi Tentang Ijtihad Kontemporer (Jakarta: Bulan Bintang, 1987), h. 126 
ISTIGHNA, Vol. 1, No 1, Januari 2018 P-ISSN 1979-2824

Homepage: http://e-journal.stit-islamic-village.ac.id/index.php/istighna

Aprianif

Taklif Dewasa Dini Dalam Hukum Islam

(Analisis Pubertas Prekoks dan Gifted)

pembatasan pembidangan ilmu yang semakin ketat dan sempit. Karena itu, menurut penulis ijtihad jama'i ini sangat diperlukan. ${ }^{186}$

Melihat kepada dua pembagian ijtihad ini, maka ijtihad yang bisa penulis lakukan dalam masalah konsep taklif ini adalah ijtihad intiqai, yaitu ijtihad dengan membandingkan berbagai pendapat para ulama terdahulu dalam masalah konsep taklif tersebut dan kemudian disesuaikan, mana kira-kira yang paling maslahat dan paling sesuai dengan kondisi umat hari ini. Karena itu, setelah memperhatikan dan menimbang berbagai pendapat ulama tentang masalah taklif, penulis sepakat dengan apa yang disampaikan oleh imam Nawawi al-Bantani (w.1314 H) di dalam kitabnya Kashifatush Shaja Sharah Safinatun Naja, mengutip pendapatnya imam Syafi'i. Beliau mengatakan,

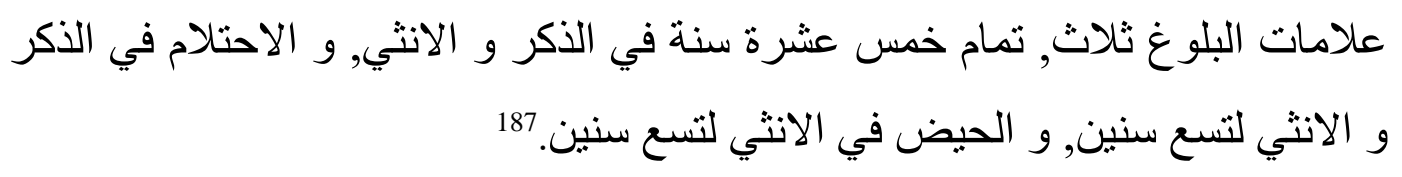

Artinya: "Tanda balig itu ada tiga, telah sempurna 15 tahun untuk laki-laki dan perempuan, bermimpi (keluar air mani) untuk laki-laki dan perempuan minimal usia 9 tahun, dan haid bagi perempuan minimal berusia 9 tahun juga."

Dalam kitabnya ini, imam Nawawi al-Bantani mengatakan bahwa ada batasan usia minimal dalam menentukan balig seseorang, dan hal ini sangat krusial menurut penulis. Karena jika batasan usia minimal ini tidak ada, maka akan banyak terjadi kekacauan-kekacauan. Bukankah di dalam mazhab Syafi'i, sebagian mazhab Hanafi dan mazhab Imamiyah batasan usia minimal balig itu memang ada. Ulama mazhab Syafi'i dan sebagian ulama mazhab Imamiyah menyatakan bahwa balig hanya bisa dicapai oleh seseorang ketika ia berusia minimal 9 tahun. Sedangkan sebagian ulama mazhab Hanafi menyatakan bahwa patokan dasar balig itu adalah berusia serendah-rendahnya 12 tahun bagi laki-laki dan berusia serendah-rendahnya 9 tahun bagi perempuan.

\footnotetext{
${ }^{186}$ Ali Hasballah, Usul at-Tashri' al-Islami, Cet V (Cairo: Dar al-Ma'arif, 1986), h. 108

${ }^{187} \mathrm{Abu}$ 'Adil Mu'ti Nawawi Ibn Umar Al-Bantani Al-Jawi, Kashifatush Shaja Sharah Safinatun Naja (Beirut: Dar Ibn Hazm, 2011), 39.
} 
ISTIGHNA, Vol. 1, No 1, Januari 2018 P-ISSN 1979-2824

Homepage: http://e-journal.stit-islamic-village.ac.id/index.php/istighna

Aprianif

Taklif Dewasa Dini Dalam Hukum Islam

(Analisis Pubertas Prekoks dan Gifted)

Dalam mazhab Syafi'i dikatakan bahwa, batasan usia minimal 9 tahun ini adalah ijtihadnya imam Syafi'i. Setelah melalui استقراع او بحث (penelitian) yang panjang dan melelahkan, yang penuh dengan kehati-hatian dan pertimbangan, imam Syafi'i berijtihad bahwa usia minimal balig itu adalah 9 tahun. Ijtihad yang beliau lakukan, tentunya tidak hanya ijtihad secara dzahiri saja, tetapi juga ijtihad secara bathini, meminta petunjuk kepada al-Hakim, Allah Swt. Karena itu, karena penulis adalah seseorang yang bermazhab Syafi'i, pendapat adanya batasan usia minimal balig 9 tahun ini, sangat penulis setujui.

Imam Syafi'i mengatakan bahwa tidak mungkin rasanya seseorang akan mengeluarkan air mani ataupun haid dibawah usia 9 tahun. Jikapun ada, itu sangatlah jarang (nadir), karena memang dimasa beliau kejadian ini bisa hampir dikatakan tidak ada. Itulah sebabnya kenapa, jika ada yang mengeluarkan air mani ataupun haid dibawah usia 9 tahun, menurut imam Syafi'i mereka tetap dihitung belum balig. Bukankah dalam ilmu Fiqh ada sebuah kaedah yang menyatakan bahwa النادر كالاعدام, الاعدام كالمعدوم (yang jarang itu dihitung tiada, dan yang tiada itu ditiadakan). ${ }^{188}$

Kemudian selanjutnya bagaimana dengan masa sekarang ini, apakah batasan usia minimal 9 tahun ini masih berlaku? Andaikan masih berlaku, dan menurut penulis itu masih berlaku, maka artinya anak-anak yang menderita pubertas prekoks jika ia keluar air mani ataupun haid dibawah usia 9 tahun, maka ia dihitung belum balig, tetapi jika ia keluar air mani ataupun haid diatas usia 9 tahun, maka ia dihitung sudah balig. Tidak peduli seperti apapun keadaannya, konsekwensinya ketika ia dihitung sudah balig, tentunya ia sudah dianggap sebagai orang yang sudah dewasa dan pastinya sudah dikenai beban taklif.

Tetapi selanjutnya mungkinkah batasan usia minimal balig ini bisa dirubah, baik ditambah ataupun dikurangi, ataupun mungkin konsep taklif itu sendiri yang dirubah. Untuk menjawab pertanyaan ini, maka perlu tentunya dilakukan ijtihad insya' $i$, dan penulis tidak mempunyai kemampuan untuk itu. Jika hal ini mungkin dilakukan, maka pastinya ia membutuhkan penelitian yang sangat mendalam. Perlu kesungguhan yang sangat besar dan tentunya dilakukan oleh seseorang yang

\footnotetext{
${ }^{188}$ Asy-Syarbini al-Khatib, Mughni al Muhtaj Sharh al-Minhaj, Juz II, 166-170.
} 
ISTIGHNA, Vol. 1, No 1, Januari 2018 P-ISSN 1979-2824

Homepage: http://e-journal.stit-islamic-village.ac.id/index.php/istighna

Aprianif

Taklif Dewasa Dini Dalam Hukum Islam

(Analisis Pubertas Prekoks dan Gifted)

mempunyai keilmuan yang mumpuni. Setidaknya seseorang yang melakukannya tersebut harus memiliki lima sarat mujtahid, ia mempunyai pengetahuan yang mendalam tentang Al-Quran dan as-Sunnah, mengetahui persoalan-persoalan yang menjadi ijma' ulama terdahulu, mengerti bahasa Arab, mengusai ilmu Usul Fiqh, dan memahami maqasid syari'ah (maksud syara' dalam pengsyari'atan hukum). ${ }^{189}$

Selanjutnya ketika ada seseorang yang didalam dirinya terpenuhi syaratsyarat intelektual seorang mujtahid tersebut, maka kemungkinan ijtihad jama'i bisa ia lakukan, yaitu dengan mengumpulkan berbagai ahli yang terkait dengan permasalahan balig ini. Kemudian ditanyakan kepada mereka segala seluk beluknya. Berbagai ahli yang terkait disini tentunya ada ahli Fiqh, Kedokteran, Psikologi, Sosiologi, Hukum, Perkembangan, ahli Gizi, ahli Usul Fiqh dan berbagai ahli lainnya. Kemudian jika seandainya semua hal ini bisa terpenuhi maka penulis akan sangat mengakpresiasi sekali terjadinya ijtihad insya'i ini.

\section{Dalil Mesti Adanya Batasan Usia 9 Tahun Dalam Konsep Taklif}

Menurut penulis diantara dalil-dalil atau alasan-alasan kenapa mesti ada batasan usia 9 tahun dalam konsep taklif adalah:

1. 'Urf

'Urf merupakan dalil utama mesti adanya batasan usia 9 tahun dalam konsep taklif menurut penulis. Sebagaimana diketahui secara bahasa 'urf artinya adalah kebiasaan, segala sesuatu yang baik, baik itu berupa bahasa ataupun tindakan, yang jelas ia berlaku di tengah kehidupan masyarakat dan masyarakat tidak asing baginya. ${ }^{190}$ Pengertian ini bisa dirujuk dalam AlQuran surat al-A'raf (7) ayat 46 dan surat al-Mursalat (77) ayat 1.

Sedangkan menurut istilah, menurut Muhammad Adib Shalih 'urf adalah ما تعارف عليه الناس او طائفة منهم و الفوه من قول او فعل, 191 segala sesuatu (baik

\footnotetext{
${ }^{189}$ Wahbah az-Zuhaili, Usul al-Fiqh al-Islami, Jilid II, 1043-1051.

${ }^{190}$ Muhammad Abu Zahrah, Usul Fiqh, 27. Kemudian bandingkan dengan pengertian 'Urf dari Amir Syarifuddin, Ushul Fiqh, Jilid II, 388. Lihat juga Mustafa Said al-Khin, al-Kafi al-Wafi fi Usul al-Fiqh al-Islami (Beirut: ar-Risalah: 2000), 215.

${ }^{191}$ Muhammad Adib Salih, Masadir at-Tashri' Wa Manahij al-Istimbat (Damasqus: atTa'awuniyah, 1968), 499. Muhammad Adib Salih adalah ketua jurusan Al-Quran dan Sunnah di Universitas Damasqus yang dilahirkan pada tahun 1926 di Damasqus Barat, Syria.
} 
ISTIGHNA, Vol. 1, No 1, Januari 2018 P-ISSN 1979-2824

Homepage: http://e-journal.stit-islamic-village.ac.id/index.php/istighna

Aprianif

Taklif Dewasa Dini Dalam Hukum Islam (Analisis Pubertas Prekoks dan Gifted)

perkataan ataupun perbuatan) yang telah dikenal dalam suatu masyarakat atau sekelompok orang serta telah mereka sepakati. Al-Jurjani mengatakan bahwa (w.1001 M) 'urf adalah ما استقرت النفوس بشهادة العقول و تلقته الطبع بالقبول, 192 segala sesuatu yang menentramkan jiwa, sesuai dengan pemikiran yang sehat serta dapat diterima sesuai dengan tabi'atnya. Sedangkan al-Khayyat ما تعارف عليه فئة من الناس او كلهم و ألفوا في البلاد mengatakan bahwa 'urf adalah 193 sesuatu yang sudah dikenal oleh sekelompok masyarakat secara luas serta mereka telah membiasakannya di seluruh negeri ataupun sebagiannya.

Merujuk kepada tiga pengertian ini maka jelaslah bahwa 'urf itu sebenarnya adalah suatu perkataan, perbuatan ataupun keadaan yang telah diterima oleh suatu masyarakat sebagai bagian dari kehidupan mereka, ataupun suatu kebiasan yang sudah melekat dan tidak dapat dipisahkan dari kehidupan mereka masyarakat sehari-hari. ${ }^{194}$ Oleh karena itu 'urf ini ada pembagian-pembagiannya. Dilihat dari segi ruang lingkup berlakunya 'urf ini terbagi dua. Ada yang bersifat umum dan ada yang bersifat khusus. 'Urf yang bersifat umum adalah kebiasaan atau keadaaan yang secara merata berlaku untuk atau di semua anggota masyarakat, meskipun berbeda tempat, masa dan budayanya. ${ }^{195}$ Contohnya adalah kebiasaan mempersilahkan

${ }^{192}$ Al-Jurnani, Kitab at-Ta'rifat (Beirut: Maktab Lubnan, 1969), 154.

${ }^{193}$ Abdul Aziz al-Khayyat, Nazariyat al-'Urf (Amman: Maktabah al-Aqsa, 1977), 21.

${ }^{194}$ Salah satu hal yang sering menjadi perdebatan dikalangan ulama adalah, apakah 'urf ini sama dengan adat. Untuk menjawab itu, maka penulis jelaskan juga disini pengertian adat. Menurut al-Jurjani adat adalah segala sesuatu (baik perkataan ataupun perbuatan) yang secara terus menerus berlaku di tengah kehidupan masyarakat, sesuai dengan penalaran serta dilakukan berulang kali. Sedangkan al-Khayyat mengatakan bahwa adat adalah sesuatu yang dilakukan berulang kali oleh seseorang, khusus ia sendiri yang melakukannya. Karena itu dari pengertian ini bisa dipahami bahwa 'urf itu lebih khusus dari pada adat, karena adat bisa ditujukan untuk kebiasaan yang dilakukan oleh seseorang saja sedangkan 'urf tidak.

Karena itu untuk memisahkan antara adat dan 'urf, al-Khayyat mengemukakan dua konsep al-'Awa'id, yaitu al-'Awa'id al-'Ammah (adat) dan al-'Awa'id al-Mutaghayyirah ('urf). Al-'Awa'id al-'Ammah adalah kebiasaan yang sama meskipun berbeda tempat, keadaan dan waktu, seperti adat makan, minum, dan lain sebagainya. Sedangkan al-'Awa'id al-Mutaghayyirah adalah kebiasaan yang berbeda karena berbeda situasi, kondisi dan tempat, seperti kebiasaan berpakaian, tempat tinggal dan lain sebagainya. Ini pendapat bagi ulama yang membedakan antara 'urf dan adat, walaupun ada juga sebagian ulama yang mengatakan bahwa antara adat dan 'urf sama saja. Lihat Al-Jurnani, Kitab at-Ta'rifat, 154 dan Abdul Aziz al-Khayyat, Nazariyat al-'Urf, 27-28.

${ }^{195}$ Biasanya 'urf yang seperti ini tidak ada seorangpun atau sekelompok masyarakatpun yang menyangkal berlakunya. Lihat Abdul Aziz al-Khayyat, Nazariyat al-'Urf, 33. 
ISTIGHNA, Vol. 1, No 1, Januari 2018 P-ISSN 1979-2824

Homepage: http://e-journal.stit-islamic-village.ac.id/index.php/istighna

Aprianif

Taklif Dewasa Dini Dalam Hukum Islam (Analisis Pubertas Prekoks dan Gifted)

orang-orang terhormat untuk mengambil tempat atau makanan terlebih dahulu, ataupun tentang ketentuan pembatasan berat benda bawaan penumpang ke kabin pesawat umpamanya. Ini sudah berlaku di seluruh dunia, meskipun berbeda tempat, waktu dan budaya. Sedangkan 'urf yang bersifat khusus itu adalah kebiasaan-kebiasaan yang berlaku hanya pada sebagian masyarakat saja ataupun pada sekelompok orang saja. Contohnya seperti kebiasaan diantara para petani, kebiasaan diantara pada pedagang, ataupun kebiasaan-kebiasaan pada kelompok-kelompok tertentu. ${ }^{196}$

Kemudian apabila ditinjau dari segi berlaku atau tidaknya suatu 'urf untuk dijadikan sebagai landasan dalam menetapkan suatu hukum, maka 'urf inipun terbagi dua juga. Ada'urf shahih dan ada'urf fasid.'Urf shahih adalah Segala sesuatu yang telah menjadi kebiasaaan dalam suatu masyarakat, dan ia tidak bertentangan dengan ketentuan nass, serta tidak juga menghilangkan kemaslahatan ataupun mendatangkan kerusakan. Maksudnya adalah ketika ada suatu 'urf, suatu tradisi atau suatu kebiasaan, tidak bertentangan dengan Al-Quran dan as-Sunnah, kemudian tidak juga membawa kepada kerusakan dan bahkan mendatangkan kemaslahatan, maka ia bisa dianggap sebagai sesuatu yang shahih atau sesuatu yang benar. Sedangkan'urf fasid, lawan dari 'urf shahih. Ia adalah ما خلف بعض ادلة الثرع او بعض قواعده الاساسية, segala sesuatu (kebiasaan) yang menyalahi sebagian dalil-dalil syara', ataupun sebagian prinsip-prinsip pokoknya syara'. Maksudnya adalah ketika ada suatu 'urf, suatu tradisi atau suatu kebiasaan secara nyata bertentangan dengan nass syara' ataupun bertentangan dengan tujuan-tujuan syara', maka ia bisa dianggap sebagai'urf fasid, 'urf yang tidak benar, dan ia mesti dibuang dan dihapus dalam kehidupan masyarakat. Tanda dari 'urf ini

${ }^{196}$ Berbicara tentang 'urf khusus ini, ia biasanya lebih banyak dan lebih bervariasi dari 'urf umum. Hal ini disebabkan karena manusia adalah makhluk sosial yang terdiri dari suku-suku dan bangsa-bangsa. Kemaslahatan dan kebutuhan mereka dalam menjalani hidup tentu berbeda-beda pula, karena itu biasanya kebiasaan-kebiasaan mereka akan berbeda-beda juga. Lihat Abdul Wahab Khalaf, Mas\}adir at-Tashri' fi Ma La Nass fih, 89.

${ }^{197}$ Kemaslahatan disini tentunya adalah kemaslahatan yang sesuai dengan ukuran-ukuran syara'. Lihat Abdul Wahab Khalaf, Ilmu Ushul Fiqh (Jakarta: Al-Majalis al-A'la al-Indonesia li alDa'wah al-Islamiyah, 1972), 146. 
ISTIGHNA, Vol. 1, No 1, Januari 2018 P-ISSN 1979-2824

Homepage: http://e-journal.stit-islamic-village.ac.id/index.php/istighna

Aprianif

Taklif Dewasa Dini Dalam Hukum Islam (Analisis Pubertas Prekoks dan Gifted)

mudah saja, yaitu lihat dari kemudharatan yang diakibatkannya, karena biasanya 'urffasid selalu akan mendatangkan kemudharatan dan kerugian.

Selanjutnya ketika ada suatu 'urf atau suatu kebiasaan sudah mapan, sudah melekat dalam suatu masyarakat, kemudian didalamnya juga terdapat kemaslahatan dan ia juga sejalan dengan nass dan tujuan-tujuan syara', maka menurut ulama Usul Fiqh, 'urf yang seperti ini bisa dijadikan sebagai bagian dari ketentuan-ketentuan hukum dalam suatu masyarakat. Karena dalam hukum Islam itu ada suatu kaidah yang berbunyi, العدة محكمة (kebiasaan yang dijadikan hukum). ${ }^{198}$ Contohnya adalah dalam suatu masyarakat, mereka sudah biasa melakukan transaksi jual beli tampa sighat umpamanya. Mereka biasa melakukan transaksi itu dengan cara ta'ati saja, penjual memberikan barang kepada si pembeli dan si pembeli memberikan bayarannya dan menerima barangnya, tampa ada ucapan ijab qabul. Maka jika kebiasaan seperti ini sudah melekat pada suatu masyarakat, maka kebiasaan itu bisa dijadikan sebagai bagian dari hukum Islam dalam masyarakat tersebut. Sehingga ketika mereka melakukan transaksi jual beli, itu cukup hanya dengan cara ta'ati saja, transaksinya dihitung sah. ${ }^{199}$ Dan untuk konsep taklif ini, menurut hemat penulis kaidah العدة محكمة juga berlaku kepadanya. Ketika ada seorang Hakim umpamanya, ingin menentukan apakah seseorang sudah taklif dalam suatu masyarakat atau belum, maka perlu kiranya baginya untuk memperhatikan'urf taklif dalam masyarakat tersebut. Karena jika tidak, maka bisa saja ia keliru. Bisa saja ada seorang anak yang sepertinya kelihatannya sudah taklif mungkin karena sudah menstruasi atau keluar air mani, tetapi dalam kenyataannya ternyata menstruasi atau keluar air maninya itu disebabkan oleh berbagai macam faktor yang mempengaruhinya, bisa jadi menstruasi atau keluar air maninya itu tidak murni benar-benar menstruasi atau keluar air mani, dan ini bisa saja terjadi. Apalagi di zaman modern ini, banyak keanehan-keanehan dan problematika-problematika yang berkembang di masyarakat. Karena itu

\footnotetext{
${ }^{198}$ Nasrun Haroen, Ushul Fiqh 1, 143.

${ }^{199}$ Abdul Wahab Khalaf, Masadir at-Tashri' fi Ma La Nass fih, 89.
} 
ISTIGHNA, Vol. 1, No 1, Januari 2018 P-ISSN 1979-2824

Homepage: http://e-journal.stit-islamic-village.ac.id/index.php/istighna

Aprianif

Taklif Dewasa Dini Dalam Hukum Islam

(Analisis Pubertas Prekoks dan Gifted)

menurut hemat penulis dalam masalah konsep taklif perlu sekali untuk memperhatikan 'urf.

Selanjutnya ketika berbicara tentang 'urf, maksudnya 'urf taklif, ulama Syafi'iyah dan Imamiyah sudah mengatakan bahwa, sebagaimana yang sudah penulis jelaskan sebelumnya, minimal usia taklif itu'urfan (secara 'urf) adalah usia 9 tahun. Karena itu jika ada yang menstruasi atau keluar air mani di bawah usia 9 tahun itu bisa dihitung belum taklif. Selain itu kalaupun ada yang benar-benar keluar air mani ataupun haid dibawah usia 9 tahun itu sangatlah jarang, dan ketentuannya yang jarang dalam hukum Islam, itu tidak bisa dijadikan patokan hukum, النادر لا حكم له (yang jarang terjadi, tidak ada hukum baginya). Kaidah lain cabang dari العادة محكمة juga mengatakan الحكم بالمعتاد لا بالنادر (hukum itu mencakup apa yang biasa terjadi, bukan apa yang jarang terjadi).

2. Adanya Dimensi Hikmah dan Maslahah

Selanjutnya dalil kedua tentang mesti adanya batasan usia 9 tahun dalam konsep taklif setelah 'urf adalah adanya dimensi hikmah dan maslahah. Perlu diketahui bahwa dijadikannya 'urf sebagai suatu bagian dari hukum Islam itu sebenarnya tidak lain adalah merupakan perwujudan dari kemaslahatan. Karena ketika ada suatu 'urf, yang mana ia tidak bertentangan dengan nass, maka biasanya didalamnya mesti terdapat kemaslahatan, dan ketika didalamnya terdapat kemaslahatan, maka disana tentu ada keridhaan حيثما وجدت المصلحة فنم وجه Allah Swt. Ahmad al-Zarqa' pernah mengatakan dimana saja engkau menemui kemaslahatan maka disana akan ditemukan keridhaan Allah Swt. Itu jugalah kenapa dalam masalah perubahan dan adaptasi hukum dalam hukum Islam, dimensi hikmah dan maslahah dikatakan biasanya selalu bisa menyediakan ruang untuk perubahan hukum. $^{201}$

${ }^{200}$ Ahmad al-Zarqa', al-Madkhal al-Figh al-'Am (Damaskus: Dar al-Fikr, 1968), 863.

${ }^{201}$ Hikmah ada yang mengartikan sama atau sinonim dengan filsafat. Namun Rashid Rida mendefinisikan bahwa hikmah itu adalah suatu ilmu tentang kebenaran yang menyebabkan kehendak untuk melakukan sesuatu yang bermanfaat karena didalamnya mengandung pemahaman secara mendalam tentang permasalahan hukum dan asrar persoalan. Lihat Muhammad Rashid Rida, Tafsir al-Manar, Jilid III (Beirut: Dar al-Ma'arif, t.thn), 310. 
ISTIGHNA, Vol. 1, No 1, Januari 2018 P-ISSN 1979-2824

Homepage: http://e-journal.stit-islamic-village.ac.id/index.php/istighna

Aprianif

Taklif Dewasa Dini Dalam Hukum Islam (Analisis Pubertas Prekoks dan Gifted)

Selanjutnya ketika dikatakan dimensi hikmah dan maslahah dapat dijadikan sebagai salah satu metode pendekatan dalam perubahan hukum, maka yang dimaksud dari hikmah dan maslahah disini tentunya adalah hikmah dan maslahah yang sesuai dengan maqasid ash-Syari'ah, atau kalau dalam bahasanya Ibn Qayyim al-Jauziyyah, ar-Ruh ash-Syari'ah. Karena itu seorang mujtahid diharapkan tidak hanya terpaku pada bentuk formal suatu permasalahan hukum, tetapi ia juga mesti menggali hikmah dan maslahah dari suatu permasalahan hukum tersebut. Karena sebagaimana diketahui bersama bahwa tujuan hukum Islam itu diturunkan atau fondasi dasarnya adalah kemaslahatan bagi seluruh umat manusia. Di sinilah letaknya keadilan Allah Swt. Karena itu, segala upaya untuk mencapai kemaslahatan yang merupakan keadilan Allah mesti disyari'atkan, dan dimana saja keadilan Allah ditemukan, maka disana ada hukum Allah Swt. ${ }^{202}$

Selanjutnya apa hikmah dan maslahah jika taklif dalam hukum Islam itu dibatasi dengan batasan usia 9 tahun. Menurut hemat penulis pasti akan ada banyak hikmah dan maslahah di dalamnya. Usia 9 tahun adalah usia yang sudah cukup mapan menurut penulis. Bukankah para ulama sudah sepakat mengatakan bahwa ketika anak sudah berusia 7 tahun maka ia disebut dengan mumayyis, bisa membedakan mana yang benar dan mana yang salah. Karena itu ketika ada seorang anak sudah mengeluarkan air mani ataupun haid di usia 9 tahun, maka biasanya ia sudah cukup pandai dan cakap dalam menghadapi kehidupannya. Bukankah dikatakan didalam sejarah bahwa sayyidah Aishah Ra tinggal serumah dengan Rasulullah Saw itu di usia 9 tahun.

Selain itu hikmah yang nyata dan jelas-jelas tampak dengan pembatasan usia taklif dengan minimal usia 9 tahun tersebut adalah orang tua bisa menyiapkan pendidikan agama yang baik bagi anak-anaknya sebelum usia tersebut. Sehingga ketika anak-anak mereka sudah mentruasi atau mimpi basah di usianya yang 9 tahun, mereka sudah siap dan sudah

\footnotetext{
${ }^{202}$ Ibn Qayyim al-Jauziyyah, I'lam al-Muwaqqi'in 'an Rabb al-Alamin, Juz III, 3.
} 
ISTIGHNA, Vol. 1, No 1, Januari 2018 P-ISSN 1979-2824

Homepage: http://e-journal.stit-islamic-village.ac.id/index.php/istighna

Aprianif

Taklif Dewasa Dini Dalam Hukum Islam

(Analisis Pubertas Prekoks dan Gifted)

mengetahui kewajiban-kewajiban agama yang dibebankan kepadanya sebagai seorang muslim sejati tentunya.

Karena itu orang tua harus mengajarkan kepada anak-anaknya tentang iman (iman kepada Allah, iman kepada Rasul-Nya, iman kepada MalaikatNya, iman kepada Kitab-Nya, iman kepada hari Kiamat-Nya serta iman kepada qad\}a dan qadar-Nya. Orang tua juga mesti mengajarkan kepada anak-anaknya tentang masalah ibadah seperti taharah (bersuci), salat, puasa, zakat dan lain sebagainya. Bahkan dalam masalah salat, Rasulullah Saw pernah bersabda,

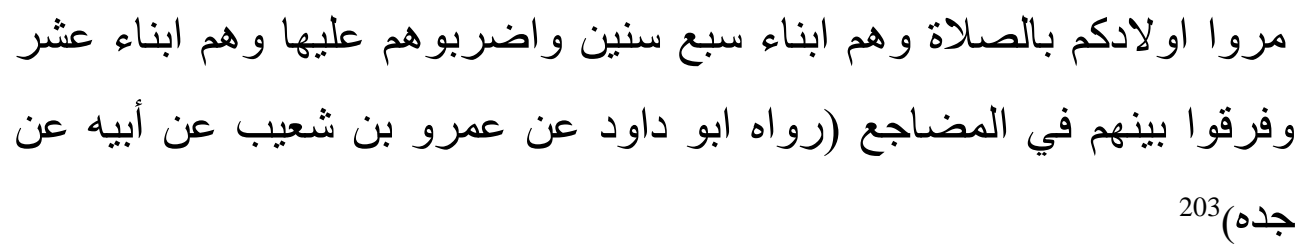

Artinya: "Suruhlah anak-anakmu salat ketika mereka berusia tujuh tahun, dan pukullah mereka ketika berusia sepuluh tahun, dan pisahkanlah mereka dari tempat tidurnya”. (HR, Abu Dawud dari 'Amr ibn Syu'aib).

Karena itu, untuk saat ini, pembatasan usia minimal 9 tahun menurut hemat penulis adalah konsep yang paling sesuai, paling mas llahłah, paling relevan untuk diterapkan, paling mencerminkan rahmat bagi umat manusia, paling dekat kepada kemudahan yang diberikan syara' dan paling utama dalam merealisir maksud dan tujuan-tujuan syara'.

\section{E. Penutup}

Kesimpulan dari penelitian ini adalah munculnya fenomena pubertas prekoks dan gifted tidaklah merubah konsep taklif yang sudah ada dalam hukum Islam. Konsep taklif yang mana bisa ditentutan dengan dua keadaan yaitu ketika seseorang sudah mampu memahami khitab syar'i dan ketika ia sudah ahli atau layak untuk menerima beban taklif (sudah balig) tidaklah berubah. Dan kesepakatan jumhur Ulama yang mengatakan bahwa batasannya adalah keluarnya

\footnotetext{
${ }^{203}$ Hadis Sahih riwayat Ibn Abi Shaibah. Lihat Sunan Abu Daud no 418. Imam an-Nawawi mengatakan hadis ini hasan. Lihat Muchlis M Hanafi, dkk, Pendidikan, Pembangunan Karakter dan Pengembangan Sumber Daya Manusia (Tafsir Al-Quran Tematik) (Jakarta: Lajnah Pentashihan Mushaf Al-Quran, 2010), 222-223.
} 
ISTIGHNA, Vol. 1, No 1, Januari 2018 P-ISSN 1979-2824

Homepage: http://e-journal.stit-islamic-village.ac.id/index.php/istighna

Aprianif

Taklif Dewasa Dini Dalam Hukum Islam

(Analisis Pubertas Prekoks dan Gifted)

air mani kali pertama bagi anak laki-laki dan keluarnya haid kali pertama bagi anak perempuan, dan kemudian jika seandainya air mani ataupun haid tersebut tidak keluar, maka batasan usia yang dipakai adalah usia genap 15 tahun tetaplah berlaku.

Tetapi kemudian konsep dasar taklif ini demi kemaslahatan dan keadilan, mesti diberikan batasan, dan ini sesuai dengan pendapat imam Syafi'i Rahimahullah yang mengatakan bahwa mesti ada batasan usia minimal dalam balig seseorang, dan beliau sudah menetapkan bahwa batasan usia minilmal tersebut adalah usia 9 tahun. Karena itu jika ada seorang anak yang sudah keluar menarche atau air mani di usia dibawah 9 tahun, maka ia dihitung belum balig.

Pendapat ini menurut penulis adalah pendapat yang paling sesuai, paling maslahah, paling relevan diterapkan, paling mencerminkan rahmat bagi umat manusia, paling dekat kepada kemudahan yang diberikan syara' dan pastinya paling utama dalam merealisir maksud dan tujuan-tujuan syara'.

Tetapi selanjutnya, batasan ini ataupun konsep ini, bukanlah merupakan suatu keputusan final, ia masih bisa berubah, tetapi tentunya perubahan tersebut dilakukan oleh seorang mujtahid munsi. Jika ada seorang mujtahid munsi yang ingin merubah konsep ini umpamanya, maka itu adalah hal yang sangat bagus sekali, tetapi pastinya dalam hal ini akan ada banyak pertimbangan dan berbagai ahli yang akan terlibat. At-Taharrur al-Fikr (kebebasan berfikir) dan berijtihad itu selalu terbuka kepada siapapun, tetapi tentunya terhadap persoalan-persoalan yang tidak ada nass-nya dan persoalan-persoalan yang termasuk kedalam kategori zanniyat.

\section{DAFTAR PUSTAKA}

'Azb 'Abdul 'Al, Abdul Hay, Ushul al-Fiqh al-Muyassar, (Cairo: Universitas alAzhar ash-Sharif, 2006)

A Proverawati, S Misaroh. Menarche Menstruasi Pertama yang Penuh Makna. (Yogyakarta: Muha Medika, 2009)

Abu Zahrah, Muhammad.Ushul Fiqh, (Cairo: Dar al-Fikr, 1988)

Al-Amidi, Sayfuddin. Al-Ihkam fi Ushul al-Ahkam, (Beirut: Dar al-Kutub al'ilmiyyah, 1983) 
ISTIGHNA, Vol. 1, No 1, Januari 2018 P-ISSN 1979-2824

Homepage: http://e-journal.stit-islamic-village.ac.id/index.php/istighna

Aprianif

Taklif Dewasa Dini Dalam Hukum Islam

(Analisis Pubertas Prekoks dan Gifted)

Al-Asnawi, Nihayat al-Ushul Sarah Minhaj al-Ushul, (Beirut: Dar al-Fikr, t.thn.)

B Hurlock, Elizabeth. Developmental Psychology, (New Delhi: Tata Mc GrawHill Publishing Company Ltd, 1981)

-----------Psikologi Perkembangan, Suatu Pendekatan Sepanjang Rentang Kehidupan, (Jakarta: Erlangga, 1995)

Baron RA, Byrne D. Social Psychology: Understanding Human Interaction, (Boston: Allyn \& Bacon, 1994)

Calon, PJA. De Jongen, De Psychologie Van De Jongen Van De Laatste School Jaren Tot Aan De Volwassen Leeftijd, (Heemstede: De Tooms, 1953)

Clark, B. Growing Up Gifted: Developing the Potential of Children at Home and at School. Edisi II. (Columbus: Charles E. Merril Publishing Company,1983)

Coleman, LJ. Scholling the Gifted, (New York: Addison-Wesley Publishing Company, 1985)

Dirjen Pembinaan Kesehatan Masyarakat Departemen Kesehatan RI, Materi Inti Kesehatan Reproduksi Remaja, (Jakarta: Depkes RI, 2001)

Al-Ghazali, Muhammad Abu Hamid. al-Mustashfa fi'Ilmi al-Ushul, (Beirut: Dar al-Kutub al-'Ilmiyyah, 1983)

Greenspan, FS. Basic and Clinical Endrocrinology 3. Edisi III, (San Fransisco: Lange, 1992)

Hallahan, Daniel P, Kauffman, James M. Exceptional Children Introduction to Special Education. (New York: Prentice-Hall Inc, 1982)

Harjaningrum, Agnes Tri, Dkk. Peranan Orang Tua Dan Praktisi Dalam Membantu Tumbuh Kembang Anak Berbakat Melalui Pemahaman Teori Dan Tren Pendidikan, (Jakarta: Prenada Media Group, 2007)

Haroen, Nasrun, Ushul Fiqh, (Jakarta: Logos Wacana Ilmu, 2001)

Hill, JP, Monks, FJ. Adolescence and Youth in Prospect, (Guilford: IPC Science and Technology Press, 1977)

Ibn Umar Al-Bantani Al-Jawi, Abu Adil Mu'thi Nawawi, Kashifatush Shaja Sharah Safinatun Naja. (Beirut: Dar Ibn Hazm, 2001) 
ISTIGHNA, Vol. 1, No 1, Januari 2018 P-ISSN 1979-2824

Homepage: http://e-journal.stit-islamic-village.ac.id/index.php/istighna

Aprianif

Taklif Dewasa Dini Dalam Hukum Islam

(Analisis Pubertas Prekoks dan Gifted)

Ibn Mughirah al-Bukhari, Muhaammad bin Isma'il bin Ibrahim, Sahih al-Bukhari, Juz III. (ttp,: Dar al-Fikr, 1981)

Ibn Surah at-Tarmizi, Muhammad Ibn 'Isa. Sunan at-Turmuzi, (ttp,: Dar al-Fikr, 1978)

Ibn Syaukani, Muhammad Ibn Ali, Nail al-Awthar, Cet II. Jilid IV. (Cairo: Musthofa al-Bab al-Halabi, $1371 \mathrm{H}$ )

Ibn Qudamah, Abdullah Ibn Ahmad. Raudah an-Nadir, (Riyad: Jami'ah al-Imam Muhammad bin Su'ud, $1399 \mathrm{H}$ )

---------- al-Mugni, (Beirut: Dar Al-Kutub al-Ilmiyah, t.thn)

Ibn Rushd, Muhammad, Bidayah al-Mujtahid Wa Nihayah al-Muqtasid, (Beirut: Dar al-Jil, 1989)

J Coulson, Noel. A History of Islamic Law. Edinburgh: Edinburgh University Press, 1994.

Al-Jauziyyah, Ibn Qayyim, I'lam al-Muwaqqi'in 'an Rabb al-Alamin, (Beirut: Dar al-Jil, 1973)

Jose Batubara, RL, Triadjaja, Bambang, Pulungan, Aman B. Buku Ajar Endokrinologi Anak, Edisi I. (Jakarta: Badan Penerbit IDAI, 2010.

Kartono, Kartini. Psikologi Wanita 1 Mengenal Gadis Remaja dan Wanita Dewasa. (Bandung: Mandar Maju, 1992)

Al-Khatib, ash-Sharbini, Mughni al-Muhtaj Sharah al-Minhaj, Juz II. (Cairo: Mathba'ah al-Bab al-Halabi, t.thn)

Khalaf, Abdul Wahab, 'Ilm Ushul al-Fiqh, (Kuwait: Dar al-Qalam, 1983)

---------- Masadir at-Tashri' fi Ma La Nashsh fih, (Beirut: Dar al-Fikr, 1972)

---------- Ilmu Ushul Fiqh. Jakarta: Al-Majalis al-A'la al-Indonesia li al-Da'wah al-Islamiyah, 1972)

Al-Mahali, Imam Jalaluddin, as-Suyuthi, Jalaluddin, Tafsir al-Quran al-Karim. Juz I. (Beirut: Dar al-Fikr, 1998)

Monks, FJ, Knoers, AMP, Haditono, Siti Rahayu. Psikologi Perkembangan: Pengantar Dalam Berbagai Bagiannya. Yogyakarta: Gadjah Mada University Press, 2002. 
ISTIGHNA, Vol. 1, No 1, Januari 2018 P-ISSN 1979-2824

Homepage: http://e-journal.stit-islamic-village.ac.id/index.php/istighna

Aprianif

Taklif Dewasa Dini Dalam Hukum Islam (Analisis Pubertas Prekoks dan Gifted)

Mooij, T. Schoolproblemen Van Hoogbegaafde Kinderen, Richtlijnen Voor Passend Onderwijs. Muiderberg: Dick Coutinho, 1991.

Nata, Abuddin, Dahlan, Abdur Rahman, Amin Suma, Muhammad, Thib Raya, Ahmad, Dkk. Ensiklopedi Hukum Islam. Jakarta: PT Ichtiar Baru Van Hoeve, 1999.

An-Nawawi, Abu Zakariya Muhyuddin, Shahih Muslim bi Sharah An-Nawawi, (Beirut: Darul Khair, 1994)

At-Tirmidhi, Al-Hafiz, Sunan at-Thirmidhi, Cet I. (Riyad: Makatabaha al-Ma'arif, t.thn.)

Purwakania Hasan, Aliyah B. Psikologi Perkembangan Islami, (Jakarta: PT RajaGrafindo Persada, 2008)

Al-Qardawi, Yusuf, Al-Madkhal li Dirasat al-Fiqh al-Islami, tt.: (Dar al-Fikr, th. Al-Ijtihad Fi ash-Shari'ah al-Islamiyah Ma'a Nazarat Tahliliyah Fi Ijtihad al-Mu'ashir. Diterjemahkan oleh Syatori, Ahmad. Ijtihad Dalam Shari'at Islam Dan Beberapa Pandangan Analisi Tentang Ijtihad Kontemporer, (Jakarta: Bulan Bintang, 1987)

Al-Qarrafi, Shihabuddin. Sharh Tanqih al-Fushul fi Ikhtishar al Makhshul fi alUshul, (Cairo: Dar al-Fikr, 1973)

RE, Behrman, RM, Kliegman, HB, Jenson. Nelson Textbook of Pediatrics. Edisi 17. (Philadelphia: Saunders Elsevier Science, 2004)

-Nelson, Ilmu Kesehatan Anak. Vol III. Edisi XV, (Jakarta: EGC, 2002. Editan A Samik Wahab)

Renzulli. What Makes Giftednees: A Reexamination of the Definition of the Gifted and Talented. (California: Ventura Cauntry Superintendent Schools Office, 1979)

Ash-Shathibi, Ibrahim Ibn Musa, al-Muwafaqat fi Ushul ash-Shari'ah. (Beirut:

Dar al-Kutub al-Ilmiyah, t.thn.)

As-Syaukani, Muhammad bin Ali@bin Muh\}ammad. Nail al-Authar, (Beirut:

Dar al-Fikr, 1978)

As-Suyuthi, Jalal ad-Din, Sunan an-Nasai bi Sharh al-Hafiz Jalal ad-Din asSuyuthi. Bab T\{ala>q. H\{adith 3432. (Beirut: Dar al-Ma'rifah, t.thn.) 
ISTIGHNA, Vol. 1, No 1, Januari 2018 P-ISSN 1979-2824

Homepage: http://e-journal.stit-islamic-village.ac.id/index.php/istighna

Aprianif

Taklif Dewasa Dini Dalam Hukum Islam (Analisis Pubertas Prekoks dan Gifted)

Az-Zuhayli, Wahbah, Ushul al-Fiqh al-Islami wa Adillatuhu. Cet I. (Beirut: Dar al-Fikr, 1989) 